\title{
A comprehensive emission inventory of biogenic volatile organic compounds in Europe: improved seasonality and land-cover
}

\author{
D. C. Oderbolz ${ }^{1}$, S. Aksoyoglu ${ }^{1}$, J. Keller ${ }^{1}$, I. Barmpadimos ${ }^{1}$, R. Steinbrecher ${ }^{2}$, C. A. Skjøth ${ }^{3,4, *}$, C. Plaß-Dülmer ${ }^{5}$, \\ and A.S. H. Prévôt ${ }^{1}$ \\ ${ }^{1}$ Laboratory of Atmospheric Chemistry (LAC), Paul Scherrer Institute (PSI), 5232 Villigen PSI, Switzerland \\ ${ }^{2}$ Karlsruhe Institute of Technology, Institute of Meteorology and Climate Research, Atmospheric Environmental Research, \\ (KIT/IMK-IFU), Kreuzeckbahnstr. 19, 82467 Garmisch-Partenkirchen, Germany \\ ${ }^{3}$ Department of Physical Geography and Ecosystems Science, Lund University, Sölvegatan 12, 22362 Lund, Sweden \\ ${ }^{4}$ Faculty of Science and Technology, Department for Environmental Science, Aarhus University, P.O. Box 358, \\ Frederiksborgvej 399, 4000 Roskilde, Denmark \\ ${ }^{5}$ Deutscher Wetterdienst, Meteorologisches Observatorium Hohenpeissenberg, Albin-Schwaiger-Weg 10, 82383 \\ Hohenpeissenberg, Germany \\ *now at: National Pollen and Aerobiology Research Unit, Charles Darwin Building, University of Worcester, Henwick Grove, \\ Worcester, WR2 6AJ, UK
}

Correspondence to: S. Aksoyoglu (sebnem.aksoyoglu@psi.ch)

Received: 3 May 2012 - Published in Atmos. Chem. Phys. Discuss.: 9 August 2012

Revised: 15 January 2013 - Accepted: 31 January 2013 - Published: 15 February 2013

\begin{abstract}
Biogenic volatile organic compounds (BVOC) emitted from vegetation are important for the formation of secondary pollutants such as ozone and secondary organic aerosols (SOA) in the atmosphere. Therefore, BVOC emission are an important input for air quality models. To model these emissions with high spatial resolution, the accuracy of the underlying vegetation inventory is crucial. We present a BVOC emission model that accommodates different vegetation inventories and uses satellite-based measurements of greenness instead of pre-defined vegetation periods. This approach to seasonality implicitly treats effects caused by water or nutrient availability, altitude and latitude on a plant stand. Additionally, we test the influence of proposed seasonal variability in enzyme activity on BVOC emissions. In its present setup, the emission model calculates hourly emissions of isoprene, monoterpenes, sesquiterpenes and the oxygenated volatile organic compounds (OVOC) methanol, formaldehyde, formic acid, ethanol, acetaldehyde, acetone and acetic acid. In this study, emissions based on three different vegetation inventories are compared with each other and diurnal and seasonal variations in Europe are investigated for the year 2006. Two of these vegetation inventories require information on tree-cover as an input. We compare three dif-
\end{abstract}

ferent land-cover inventories (USGS GLCC, GLC2000 and Globcover 2.2) with respect to tree-cover. The often-used USGS GLCC land-cover inventory leads to a severe reduction of BVOC emissions due to a potential miss-attribution of broad-leaved trees and reduced tree-cover compared to the two other land-cover inventories. To account for uncertainties in the land-cover classification, we introduce land-cover correction factors for each relevant land-use category to adjust the tree-cover. The results are very sensitive to these factors within the plausible range. For June 2006, total monthly BVOC emissions decreased up to $-27 \%$ with minimal and increased up to $+71 \%$ with maximal factors, while in January 2006 , the changes in monthly BVOC emissions were -54 and $+56 \%$ with minimal and maximal factors, respectively. The new seasonality approach leads to a reduction in the annual emissions compared with non-adjusted data. The strongest reduction occurs in OVOC (up to $-32 \%$ ), the weakest in isoprene (as little as $-19 \%$ ). If also enzyme seasonality is taken into account, however, isoprene reacts with the steepest decrease of annual emissions, which are reduced by $-44 \%$ to $-49 \%$, annual emissions of monoterpenes reduce between -30 and $-35 \%$. The sensitivity of the model to changes in temperature depends on the climatic 
zone but not on the vegetation inventory. The sensitivity is higher for temperature increases of $3 \mathrm{~K}(+31 \%$ to $+64 \%)$ than decreases by the same amount $(-20$ to $-35 \%)$. The climatic zones "Cold except summer" and "arid" are most sensitive to temperature changes in January for isoprene and monoterpenes, respectively, while in June, "polar" is most sensitive to temperature for both isoprene and monoterpenes. Our model predicts the oxygenated volatile organic compounds to be the most abundant fraction of the annual European emissions (3571-5328 $\mathrm{Gg} \mathrm{yr}^{-1}$ ), followed by monoterpenes $\left(2964-4124 \mathrm{Gg} \mathrm{yr}^{-1}\right)$, isoprene $\left(1450-2650 \mathrm{Gg} \mathrm{yr}^{-1}\right)$ and sesquiterpenes $\left(150-257 \mathrm{Gg} \mathrm{yr}^{-1}\right)$. We find regions with high isoprene emissions (most notably the Iberian Peninsula), but overall, oxygenated VOC dominate with 43$45 \%$ (depending on the vegetation inventory) contribution to the total annual BVOC emissions in Europe. Isoprene contributes between 18-21\%, monoterpenes 33-36\% and sesquiterpenes contribute 1-2\%. We compare the concentrations of biogenic species simulated by an air quality model with measurements of isoprene and monoterpenes in Hohenpeissenberg (Germany) for both summer and winter. The agreement between observed and modelled concentrations is better in summer than in winter. This can partly be explained with the difficulty to model weather conditions in winter accurately, but also with the increased anthropogenic influence on the concentrations of BVOC compounds in winter. Our results suggest that land-cover inventories used to derive tree-cover must be chosen with care. Also, uncertainties in the classification of land-cover pixels must be taken into account and remain high. This problem must be addressed together with the remote sensing community. Our new approach using a greenness index for addressing seasonality of vegetation can be implemented easily in existing models. The importance of OVOC for air quality should be more deeply addressed by future studies, especially in smog chambers. Also, the fate of BVOC from the dominant region of the Iberian Peninsula should be studied more in detail.

\section{Introduction}

Biogenic Volatile Organic Compounds (BVOC) are important precursors for tropospheric chemistry. BVOCs are emitted from vegetation and in general these emissions are temperature and light-dependent (e.g. Koppmann, 2007). The most important BVOCs are thought to be the olefinic isoprene, mono- and sesquiterpenes as well as oxygenated VOC (OVOC).

The atmospheric lifetime of BVOCs vary to a large degree depending on the compound and the oxidant: at an ozone concentration of $\approx 28 \mathrm{ppbv}$, isoprene has a half-life of 1.3 days, $\alpha$-pinene (a monoterpene) a half-life of $4.6 \mathrm{~h}$ and $\beta$-caryophyllene (a sesquiterpene) of only $2 \mathrm{~min}$. Depending on the oxidant and its concentration, these half-life times can even be shorter (Atkinson and Arey, 2003). Supplement Tab. Supp1 provides half-life data and structures of important emitted BVOC compounds.

In the atmosphere, BVOCs participate in reactions leading to a large diversity of secondary products including formaldehyde, ozone (Chameides et al., 1988; Curci et al., 2009) and secondary organic aerosols (Kanakidou et al., 2000; Claeys et al., 2004; Hodzic et al., 2009; Carlton et al., 2009; Hallquist et al., 2009). Therefore, biogenic emissions as well as the anthropogenic ones are required for air quality simulations. However, there are still large uncertainties in BVOC emission estimates (Guenther et al., 2006; Steinbrecher et al., 2009; Simpson et al., 2012). Improved knowledge on BVOC emissions from either field (e.g. Bäck et al., 2012) or modelling experiments (e.g. Karl et al., 2009) is therefore highly relevant.

Modelling of BVOC is complex because several parameters are known to influence these emissions (Peñuelas and Llusià, 2001). The influence of abiotic factors such as temperature and light is relatively well known (Guenther et al., 1993, 1995; Guenther, 1997). On the other hand, the influence of water availability (especially under draught stress) is more uncertain (Duhl et al., 2008; Ormeño et al., 2007). Many biotic factors such as enzyme activity (Schnitzler et al., 1997), the age of a tree (Street et al., 1997; Niinemets, 2002) or the influence of herbivores (Arneth and Niinemets, 2010; Lucas-Barbosa et al., 2011; Berg et al., 2012) and the influence of pollutants such as ozone (Llusià et al., 2002) are even more complex. There also exist semi-natural as well as anthropogenic sources of BVOC: when wood of conifers is burned, monoterpenes are released (Ingemarsson et al., 1998; Ciccioli et al., 2001; Rouvière et al., 2006), also woodlogging operations are known to release large amounts of monoterpenes (Strömvall and Petersson, 1991). Isoprene is also a by-product of combustion processes (Reimann et al., 2000) and is also emitted by the metabolism of humans (Salerno-Kennedy and Cashman, 2005) and other mammals (Rasmussen and Perrin, 1999).

Bottom-up BVOC models can be separated into two major groups: (1) process-based models, where the emissions are modelled from first principles on the cellular level (Zimmer et al., 2003; Keenan et al., 2009); (2) empirical models such as MEGAN (Model of Emissions of Gases and Aerosols from Nature) (Guenther et al., 2006, 2012) or seBVOC (semi-empirical emission module) (Steinbrecher et al., 2009) that use empirical formulas to describe emissions on the tree level. The model discussed in this paper belongs to the second group.

Studies on the aerosol composition in Switzerland and in Europe have shown that SOA is a major constituent of the fine mode (Lanz et al., 2008, 2010; Jimenez et al., 2009). Also, ${ }^{14} \mathrm{C}$ analysis showed that a major fraction of the SOA is non-fossil, which suggests that the precursors probably originate from wood burning and from biogenic emissions (Szidat et al., 2006). Recently, also cooking has been identified 
as a source of SOA (Mohr et al., 2012). One can therefore assume that BVOC are important precursors for SOA at least in summertime. We do not call such secondary organic aerosol "natural" since a large fraction of the oxidants needed for the conversion of the volatile compounds are strongly influenced by anthropogenic emissions, e.g. $\mathrm{NO}_{\mathrm{x}}$ (Carlton et al., 2010).

Air quality modelling studies for Switzerland suggest that the formation of SOA is to a large extent due to biogenic precursors such as monoterpenes and sesquiterpenes (AndreaniAksoyoglu et al., 2008; Aksoyoglu et al., 2011). These studies used tree specific emission functions of isoprene and monoterpenes for a few trees (Andreani-Aksoyoglu and Keller, 1995; Keller et al., 1995) and a simple estimation of sesquiterpenes. Similar studies (e.g. Stewart et al., 2003; Steinbrecher et al., 2009) suggested that the results of emission models are very sensitive to the underlying vegetation inventories. Studies that investigate approaches to estimate BVOC emissions from the vegetation at the species level are therefore highly relevant. According to Arneth et al. (2011), such studies should cover both the vegetation inventories and the mechanistic description of emissions from the major BVOC sources. These studies should be on a scale and resolution that is relevant for atmospheric chemistry and suitable for Chemistry Transport Models (CTM) used for studies of the fate of BVOCs. The aim of this study is to improve the understanding of $\mathrm{BVOC}$ emissions in relation to atmospheric chemistry.

First, we investigate the effect of different vegetation inventories on emission predicted by a tree specific BVOC emission model. We study the effect of three different European vegetation inventories by Simpson et al. (1999), Köble and Seufert (2001) and Skjøth et al. (2008a), respectively. Second, we study the influence of the use the three different global land-cover inventories based on data of the AVHRR satellite (USGS GLCC), the SPOT satellite (GLC2000) and the Envisat satellite (Globcover) on projecting BVOC emissions. We discuss the results in relation to the four main groups of BVOCs: isoprene, monoterpenes, sesquiterpenes and oxygenated VOC, respectively. Further, we will compare simulations of concentrations of isoprene and monoterpenes using the CAMx model to observations of ambient air concentrations in summer and winter at Hohenpeissenberg in 2006.

The year 2006 was chosen for BVOC modelling as our laboratory performed detailed atmospheric aerosol field studies in January and June of this year. These BVOC emissions will be used for a future publication on the effect of BVOC emissions on both continental as well as on regional scale.

\section{Methodology}

\subsection{Biogenic VOC species}

The biogenic species included in this study are isoprene (ISOP), monoterpenes (MT), sesquiterpenes (SQT) and the most important oxygenated VOC compounds (OVOC): methanol, formaldehyde, formic acid, ethanol, acetaldehyde, acetone and acetic acid. OVOCs are discussed as one lumped species (OVOC) with a molar mass of $38.83 \mathrm{~g} \mathrm{~mol}^{-1}$ (Tab. Supp2). Chemically, the first three classes are related: ISOP (2-methyl-1,3-butadiene) is the building block for MT (2 ISOP skeletons) and SQT (3 ISOP skeletons). Globally, ISOP dominates the biogenic emissions - about half of the global BVOC emissions are ISOP (Guenther et al., 2012), half of which stems from tropical broad-leaved trees (Guenther et al., 2006). As we will show later, this is not the case for Europe under the assumptions used here.

This paper focuses on constitutive BVOC, that is BVOC emissions which occur under normal and stress conditions, but which are limited to specific emitting plants (as defined by Niinemets (2010b)). We do not treat stress-induced emissions of BVOC, which have been shown to occur from a broader range of plants, which are, however, difficult to quantify.

The most important species emitted by plants are depicted in Tab. Supp1. In our model, the individual chemical compounds of each class are lumped. We assume that the emission characteristics of the compounds within one class do not differ, although this assumption does not always hold in nature (Staudt et al., 2000; Hakola et al., 2006).

Although BVOC species are emitted mainly by trees, we included emissions from agriculture and grass as well for completeness. These vegetation types were derived from Globcover 2.2 data in the same way for S1 and S2 while they were already present in S3. The classification of trees is very important for emission calculations. We classified trees not only as needle-leaved (conifers) and broad-leaved, but also distinguished between deciduous and evergreen trees, as suggested by Steinbrecher et al. (2009). All possible combinations of these classes do occur: deciduous broad-leaved (e.g. Beech), deciduous needle-leaved (e.g. Larch), evergreen broad-leaved (e.g. Eucalyptus), evergreen needle-leaved (e.g. Pine) (Tab. Supp3).

\subsection{Air quality model system}

The biogenic emission model requires meteorological parameters such as temperature and irradiance to adjust the emissions to the environmental conditions. The meteorological model Weather Research and Forecasting Model (WRF) version 3.2.1 (Michalakes et al., 2004) was used to simulate meteorological parameters for January and June 2006. The initial and boundary conditions for WRF were derived from the ECMWF ERA40 reanalysis (Uppala et al., 2005) 
(available every $6 \mathrm{~h}$ ), snow data was refined using 8-day average MODIS snow cover MOD10C2 from NASA (available from http://modis-snow-ice.gsfc.nasa.gov). For WRF, one domain with a horizontal resolution of $0.25 \times 0.125^{\circ}$ and $31 \sigma$ layers (lowest layer depth: $20 \mathrm{~m}$, top of the domain at about 17000 ma.s.l.) was used. The domain has an extent of $15.0^{\circ} \mathrm{W}$ to $35.0^{\circ} \mathrm{E}$ of longitude and 35.0 to $70.0^{\circ} \mathrm{N}$ of latitude, which results in 200 by 280 cells in each layer. The surface layer physics (Monin-Obukhov) and boundary layer parameterisation (Mellor-Yamada-Janjic) is based on the work of Janjic (1994). Data in the layers above $1 \mathrm{~km}$ above ground was nudged towards ECMWF data.

We calculated the gas phase BVOC concentrations using the air quality model CAMx (Comprehensive Air Quality Model with extensions, version 5.30, ENVIRON, 2010) for the same time period in order to compare them with available measurements. The horizontal resolution of the domain for CAMx is the same as for WRF, but uses only $14 \sigma$ layers (lowest layer depth: $20 \mathrm{~m}$, top of the domain at about 7000 ma.s.1.). Anthropogenic emissions are based on the MACC 2006 inventory provided by TNO (Kuenen et al., 2011) and were kept constant for the different scenarios. All CAMx simulations were carried out using the CAMxRunner (Oderbolz et al., 2012), a modular control environment for CAMx.

\subsection{Emission model}

The biogenic emission model used so far at the Paul Scherrer Institute was designed for the most abundant tree species in Switzerland (Andreani-Aksoyoglu and Keller, 1995; Keller et al., 1995). It was based on limited data about the emission rates of those species. The new, array-based approach discussed here is able to efficiently calculate emission data for an arbitrary number of vegetation types. The emission model was written in IDL, version 8.0.1 which supports fast parallel operations on large arrays. This allowed us to process more than one-hundred vegetation types together. The model proceeds by stepping through each model hour and produces one file per day. This file is then merged with the anthropogenic emissions and used as input for CAMx to simulate ambient concentrations (Fig. Supp1).

BVOC emissions largely depend on temperature $(T)$ and solar radiation (photon flux) in the wavelength range from 400 to $700 \mathrm{~nm}$, which is called photosynthetically active radiation (PAR) and is measured in $\mu \mathrm{molm}^{-2} \mathrm{~s}^{-1}$. The emission model distinguishes between synthesis (depending on both temperature and light) and pool emissions (depending only on temperature) as suggested by Smiatek and Steinbrecher (2006). ISOP emission is treated as pure synthesis emission whereas MT comprise of both synthesis (MTS) and pool (MTP) emission. On the other hand OVOC and SQT emissions are treated as pure pool emissions.

The basic equations for the emission rates are derived from the widely accepted formulas by Guenther (Guenther et al.,
1995; Guenther, 1997):

$$
\begin{aligned}
E_{\mathrm{ISOP}, i} & =A_{i} \times e_{0, \mathrm{ISOP}, i} \times D_{i} \times \gamma_{\mathrm{S}}(\mathrm{PAR}, T) \times C_{\mathrm{ISOP}, i} \\
E_{\mathrm{MTS}, i} & =A_{i} \times e_{0, \mathrm{MTS}, i} \times D_{i} \times \gamma_{\mathrm{S}}(\mathrm{PAR}, T) \times C_{\mathrm{MTS}, i} \\
E_{\mathrm{MTP}, i} & =A_{i} \times e_{0, \mathrm{MTP}, i} \times D_{i} \times \gamma_{\mathrm{P}}(T) \times C_{\mathrm{MTP}, i} \\
E_{\mathrm{SQT}, i} & =A_{i} \times e_{0, \mathrm{SQT}, i} \times D_{i} \times \gamma_{\mathrm{P}}(T) \times C_{\mathrm{SQT}, i} \\
E_{\mathrm{OVOC}, i} & =A_{i} \times e_{0, \mathrm{OVOC}, i} \times D_{i} \times \gamma_{\mathrm{P}}(T) \times C_{\mathrm{OVOC}, i}
\end{aligned}
$$

where $i$ is the vegetation type, $E$ is the emission rate of a chemical compound in $\mu \mathrm{gh}^{-1}$ cell $^{-1}, A$ is the projected area covered by vegetation type (for trees this is the crown closure) $i$ in a grid cell in $\mathrm{m}^{2}, e_{0}$ is the basal emission rate in $\mu \mathrm{g} \mathrm{h}^{-1} \mathrm{~g}_{\mathrm{dw}}^{-1}$ at $30^{\circ} \mathrm{C}$ and $\mathrm{PAR}=1000 \mu \mathrm{mol} \mathrm{m}^{-2} \mathrm{~s}^{-1}, D$ is the foliar biomass density $\left(\mathrm{g}_{\mathrm{dw}} \mathrm{m}^{-2}\right), \gamma_{\mathrm{P}}$ is the environmental correction factor for pool emissions, $\gamma_{S}$ is the environmental correction factor for synthesis emissions and $C$ is the seasonality adjustment factor which depends on the season as well as on the location. Note that both $D$ and $e_{0}$ are given in terms of the dry weight of the foliage (dw).

Values for $e_{0}, D_{i}$ are given in Tab. Supp3 that lists the values for all vegetation types considered as given in Steinbrecher et al. (2009).

\subsubsection{Basal emission rates $e_{0}$}

The basal emission rates are a crucial input to this kind of model because we assume that a given plant species produces a constant known emission of a given BVOC at standard conditions $\left(30^{\circ} \mathrm{C}\right.$ leaf temperature and $1000 \mu \mathrm{mol} \mathrm{m}^{-2} \mathrm{~s}^{-1}$ photosynthetically active radiation (PAR)). The authors are well aware that this is a simplification, because many abiotic (for example draught) but also biotic factors (for example genetic disposition) are known to have an influence on the basal emission rates of plants (Niinemets et al., 2010). However, in detail those effects are not very well studied and it would be beyond the scope of this paper to determine the effect of all known and yet unknown factors on the emission behavior of more than 100 species living in the different climatic zones of Europe. Recently, for example, Baghi et al. (2012) showed that flowering considerably contributes to the overall load of BVOCs. However, it would be an enormous endeavor just to add flowering and BVOC emission of the main European tree species - if this is currently possible at all. Herbivory can also influence BVOC emissions substantially - in a recent study, Berg et al. (2012) showed that infestation of bark beetles on lodgepole pines in Western North America can increase BVOC emissions by up to a factor of four. Because also this effect is difficult to model, we decided to limit this study to stress-free conditions.

The correct derivation of basal emission rates $e_{0}$, but also of the environmental correction factors $\gamma$ is very challenging. Niinemets et al. (2011) provide an extensive overview of potential experimental problems but also problems related to data analysis (averaging or integration). It is, for example, of vital importance that plants with specialized storage 
tissue are not mechanically stressed, otherwise, the BVOC emissions can raise by two or more orders of magnitude. The authors list ten recommendations to ensure a future standard in BVOC measurements. In the selection of emission factors or basal emission rates used for compiling the emission inventory we focus on studies where plants were not impacted by stress.

Due to increasing experimental challenges associated with high reactivity and stickiness, the quantitative determination of basal emission rates of SQT is challenging and error-prone (Niinemets et al., 2011). Thus, only for a few plant species some information on SQT emission exists. Based on the knowledge available, with the current constraints in the analysis of SQT in air samples, we assume that all plant species considered in our inventory emit SQT. Further, we assume that this compound group is emitted temperature controlled only as also shown by, for example Fares et al. (2011), despite some information exist that sunlight, beside stress, might be another controlling factor (Hansen et al., 2003). The situation for OVOC is similar to that of SQT. In a recent study on BVOC emission from Mediterranean vegetation, Bracho-Nunez et al. (2011) highlighted the uncertainty associated with the emission of OVOC including the difficulties to model this emission type. However, the authors demonstrated that oxygenated VOC are a key compound class in the total BVOC emission of the plants studied, with methanol as major compound. In the presented inventory we follow a rather pragmatic approach when modeling oxygenated VOC emission from vegetation, similar to that of SQT assuming a temperature only emission. In a study on orange, Fares et al. (2011) show that methanol emission from branches is very well parameterized by a temperature-only algorithm.

\subsubsection{Environmental correction factors $\gamma$}

The environmental correction factors $\gamma$ are empirical functions to correct the basal emission rates to a given leaf temperature $T$ and photosynthetically active radiation PAR. The form of these functions depends on the compound in question. We consider two kinds of emissions: pool $\left(\gamma_{\mathrm{P}}\right)$ and synthesis $\left(\gamma_{\mathrm{S}}\right)$. Pool emissions are related to the evaporation of stored BVOC in pools with a large capacity, a process that is decoupled from photosynthesis. In contrast to this, synthesis emissions are considered as a direct by-product of photosynthesis. Compounds may also be a mixture of both emission types as it is the case for MT.

Since ISOP is modelled as co-synthesised with carbohydrates (pure synthesis), the temperature response is similar to the response of photosynthesis. The functions used are shown in Tab. Supp4 as defined by Guenther (1997). Figs. 1 and 2 show the dependence of the $\gamma_{\mathrm{P}}$ and $\gamma_{\mathrm{S}}$ on $T$ at constant PAR and on PAR at constant $T$, respectively.

In the case of pool emissions, the temperature response of the model shows no limitation at high temperatures. To properly model the real response, the pool size and the rate of

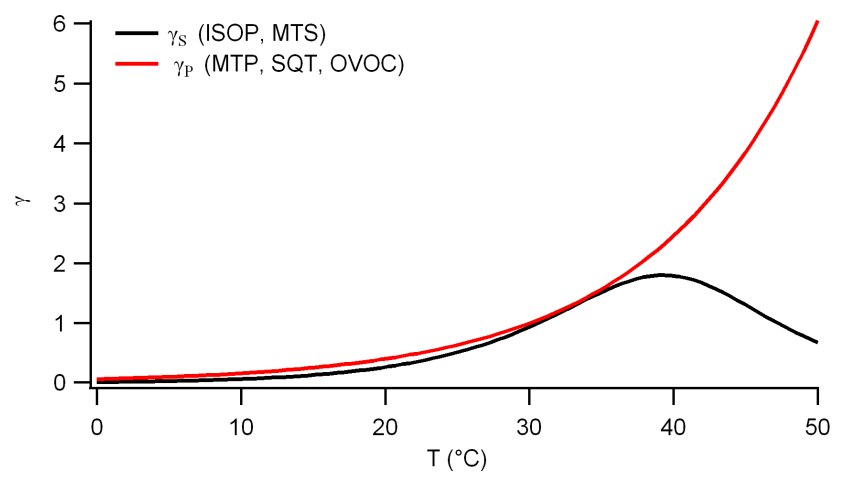

Fig. 1. Dependence of the environmental correction factors $\gamma_{\mathrm{P}}$ and $\gamma_{\mathrm{S}}$ on temperature at $\mathrm{PAR}=1000 \mu \mathrm{molm}^{-2} \mathrm{~s}^{-1}$.

the replenishment of the pools must in principle be known. However, the pool size can generally be assumed to be infinite, because theoretically, the pool capacity is high enough to sustain a constant emission of $1 \mu \mathrm{gh}^{-1} \mathrm{~g}_{\mathrm{dw}}^{-1}$ over $1500 \mathrm{~h}$ at $30^{\circ} \mathrm{C}$ based on a MT content of about $900 \mu \mathrm{gg}^{-1}$ needle fresh weight of Picea abies (Schönwitz et al., 1987) assuming a needle water content of $50 \%$ (Schmidt, 1953).

\subsubsection{Seasonality adjustment factor $C$}

Long-term seasonal fluctuation of the vegetation due to the development of leaves and needles must be taken into account. Here we use a simplified description of this complex phenomena (Battey, 2000), as a full mechanistic description of phenology including calibration values for more than 100 vegetation types still remains to be developed (Hickler et al., 2012).

The seasonality adjustment factor $C$ is used to express the low-frequency influence of the environmental conditions on the emissions of vegetation type $i$. In the formulation used here, $C$ is a function of season and of the trees' location. In our model, we are able to distinguish between two major aspects of seasonality: (1) the seasonality of the foliar biomass $\left(C_{\mathrm{b}}\right)$ and (2) the seasonality of the activity of the enzymes needed for photosynthesis $\left(C_{\mathrm{s}}\right)$ :

$C=C_{\mathrm{b}} \times C_{\mathrm{s}}$

For the vegetation type "agriculture", we set $C_{\mathrm{b}}$ to 1.0 in the months April-August and 0.0 during the rest of the year, bearing in mind that this is a simplification.

The seasonality of the foliar biomass $C_{\mathrm{b}}$ is estimated using satellite measurements of the NDVI (Normalised Difference Vegetation Index) from the MODIS instrument aboard the Terra satellite (MOD13C1). This index was chosen because it is directly correlated to the chlorophyll concentration (Huete et al., 1999) as well as to the conversion efficiency of absorbed energy of foliage (Nakaji et al., 2007). It was also used to determine the onset of flowering of birch trees (Karlsen et al., 2009). NDVI also correlates to above-ground 


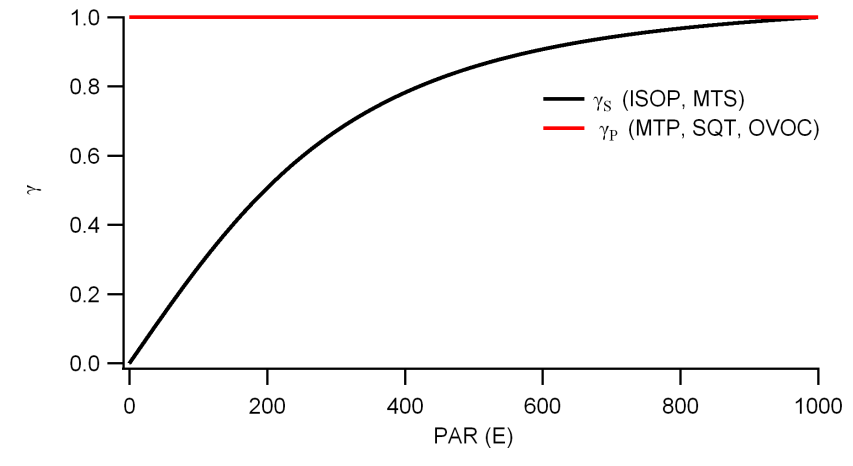

Fig. 2. Dependence of the environmental correction factors $\gamma_{\mathrm{P}}$ and $\gamma_{\mathrm{S}}$ on PAR at $T=30^{\circ}$.

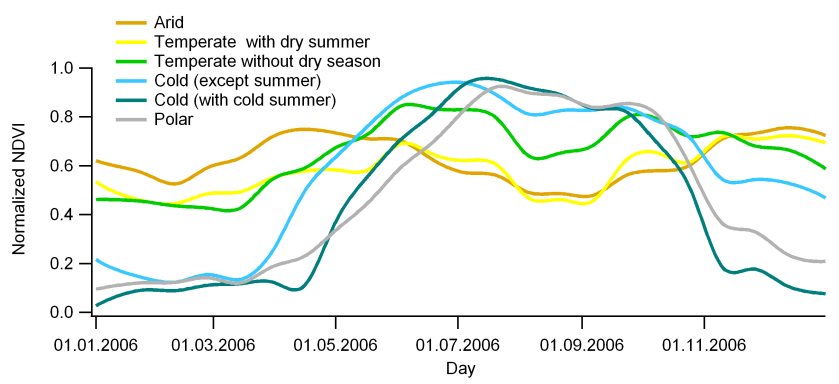

Fig. 3. Temporal evolution of average normalised NDVI in the six climatic zones.

biomass (Boelman et al., 2003) and leaf area index (LAI) (Tucker, 1979), therefore, we use it as a proxy for changes in foliar biomass. Values of NDVI are in the range $[-1,1]$ where a value of 1 indicates the maximum greenness, e.g. tropical forests (Huete et al., 1999) while negative values indicate liquid water, ice or snow.

To obtain this foliar biomass correction factor $C_{\mathrm{b}}$, we used 25 available 16-day averages of NDVI from 19 December 2005 to 3 January 2007 at a resolution of $0.05^{\circ}$ from the US Geological Survey (http://lpdaac.usgs.gov). To obtain a local relative measure of greenness, we normalised the NDVI data for each pixel by the maximum annual value of each pixel and spline-interpolated the result to daily values. Values below zero were set to zero prior to interpolation.

Since NDVI drops to or below zero (in this case we set it to zero) when snow is present, our factor suppresses emissions under snow cover. The same is true for ice and water surfaces. It has been discussed that especially emissions of MT might accumulate below a snow cover and be released on a short timescale at snow melt (Swanson et al., 2005), but this effect is currently not included in our model.

The average variation of the normalised NDVI with time is shown in Fig. 3 for the six climatic zones (see Fig. Supp2) used in this study. These zones represent an updated version of the well-known Köppen-Geiger climate classification (Peel et al., 2007). Of the original 19 climatic zones, we used an aggregate of six zones for Europe: cold except summer, cold, temperate with dry summer, temperate without dry season, arid and polar. The time of the maximum normalised NDVI varies with the zones, arid being the earliest and polar the latest.

Some zones, most notable the arid and the temperate zone show a bimodal pattern of greenness. This behaviour was also observed by Evrendilek and Gulbeyaz (2008) in Turkey, a country that consists of a wide range of climatic zones. We attribute this bi-modal behaviour of the seasonality to the higher water availability in spring and autumn and the high fraction of evergreen plants in those zones.

To account for the seasonal variability of photosynthesis enzyme activity, we introduced the factor $C_{\mathrm{S}}$ for synthesis emissions to assess the sensitivity of the model to this effect. Depending on the type of tree, different functions are used; for deciduous broad-leaved trees, the function is is derived from data from Schnitzler et al. (1997) and Lehning et al. (2001): $C_{\mathrm{s}}=a \times \exp \left(-.5 \times((\mathrm{doy}-d 0) / b)^{2}\right)$ where doy is the day of the year and the empirical factors $a=1.0091, d 0=$ $205.2055, b=36.5647$. The function for evergreen broadleaved trees is from Ciccioli et al. (2003) (Fig. Supp3).

For conifers, our model uses an approach put forward by Staudt et al. (2000), which was also used by Steinbrecher et al. (2009). The seasonal correction factor is a function of the month $(M)$ (the form of this function is bell shaped, comparable to the function for deciduous broad-leaved trees) and depends on the latitude of the location (Steinbrecher et al., 2009).

Note that when the seasonality of the enzyme activity is taken into account, the inventories are called S1e-S3e, without the e, only $C_{\mathrm{b}}$ is taken into account. This distinction is made because it cannot be precluded that there is confounding between $C_{\mathrm{s}}$ and $C_{\mathrm{b}}$, which would imply double counting of down-regulation.

\subsubsection{Canopy model}

The lower part of the plant canopy is shaded by the leaves and branches above causing a decrease of PAR with increasing distance from the canopy top. As a consequence, leaf temperature also decreases, which finally results in lower emission rates. In our approach we applied a simple Lambert-Beer-like model to assess the influence of the canopy on the radiation levels the leaves or needles are exposed to. The radiation correction is calculated for each vegetation type separately (except for agriculture and grass), by subdividing the canopy in $\mathrm{n}$ layers using downward normalised tree heights (relative to the total tree height) as z-coordinates (Niinemets, 2010a). The biomass is scaled by the relative leaf area distribution (expressed as a probability density function) in each layer (Fig. Supp4). We used ten layers for our simulations because using more layers did not alter the results significantly, but unduly increased the computation time (mostly due to memory requirements). 
We assume that the leaf angle distribution (LAD) is constant and isotropic for a given tree. Diffuse radiation is of vital importance in cloudy conditions (Ross, 1981), because it is the only source of radiation under these conditions. We assume, consistently with Baldocchi et al. (1985), that the diffuse radiation stems from an isotropic sky.

Measurements carried out in Switzerland by Leuzinger and Körner (2007) indicate that the leaf temperature of conifers is close to air temperature (max. $2.7 \mathrm{~K}$ above ambient), whereas broad-leaved trees exhibit leaf temperatures of up to $5 \mathrm{~K}$ above ambient temperature. In the model, the leaf temperature is a function of the air temperature, the radiation regime as well as the integrated heat input of the current day. This procedure is described in-depth in the Supplement (Sect. Supp1).

The numerical weather prediction model WRF predicts the light irradiance in $\mathrm{Wm}^{-2}$ which must be converted to PAR. LOWTRAN7 (Low resolution atmospheric Transmission, Kniezys et al., 1988) simulations showed that the conversion factor is rather constant over a large range of solar elevation angles. In our simulations we used a conversion factor of $2.1 \mathrm{~mol} \mathrm{~s}^{-1} \mathrm{~W}^{-1}$.

The canopy model has the strongest influence on ISOP, which annually is reduced by about $34 \%$. Annual MT emissions are reduced by $21 \%$, SQT by $11 \%$ and OVOC are reduced by about $4 \%$ in the case of S1. Total annual BVOC emissions of S1 are reduced by $18 \%$ due to the canopy model.

\subsection{Land cover and vegetation inventories}

In this study, we compare three different vegetation inventories. The first two were prepared specifically for this work and are based on the studies of Skjøth et al. (2008a) (S1) and Simpson et al. (1999) (S2), respectively. The third inventory (S3) from Köble and Seufert (2001) was not changed except for re-projection and spatial re-sampling.

For S1 and S2, we followed the work-flow illustrated in Fig. Supp5 as they require a land-cover data set in order to produce the final vegetation inventory.

\subsubsection{Land cover data associated with $\mathrm{S} 1$ and $\mathrm{S} 2$}

The basic land-cover data set for $\mathrm{S} 1$ and $\mathrm{S} 2$ is the regional product for Western Europe of the land-cover inventory Globcover 2.2 (Bontemps et al., 2011) which is based on data of the years 2005 and 2006. This data set is a categorical land-cover inventory (each pixel contains only one out of 51 land-cover categories) with a spatial resolution of $1^{\prime \prime}$ in longitudinal and latitudinal direction. We aggregated these cells into a fractional land-cover inventory using this formula:

$A_{i}=A \times f_{i} \times \sum_{c=1}^{N}\left(\frac{n_{c}}{4050} \times f_{c}\right)$ where $A$ is the area of the given cell of the model domain (the target cell), $f_{i}$ is the fraction of vegetation type $i$ in the target cell and depends on the approach used (for S1, $f_{i}$ is given in terms of conifers or broad-leaved trees, in S2 it is given in terms of forest). $c$ is the index of a Globcover 2.2 forest land-cover category, $N$ is the number of Globcover 2.2 forest land-cover categories, $n_{c}$ is the number of Globcover 2.2 cells of class $c$ in the target cell. The constant 4050 is the number of Globcover 2.2 cells per target cell, reflecting the much higher resolution of the Globcover 2.2 data set compared to the model resolution.

The land-cover correction factor $f_{c}$ describes what fraction of a pixel of type $c$ is really covered by vegetation (Tab. Supp5). These factors are average values estimated using the Globcover 2.2 documentation (Bontemps et al., 2011) - we assume that the percentages given refer to crown closure, even though this is not stated explicitly. We also tested the sensitivity of the model response to the landcover correction factors and in addition used two other landcover inventories (USGS GLCC and GLC2000) for comparison. The USGS GLCC land-cover inventory often used in conjunction with the WRF weather prediction model. This land-cover inventory is based on data acquired by the Advanced Very High Resolution Radiometer (AVHRR) instrument from April 1992 until March 1993 (http://edc2. usgs.gov/glcc/background.php). The $30^{\prime \prime}$ resolution of USGS GLCC was used. GCL2000 is a predecessor of Globcover 2.2 (Hartley et al., 2006).

\subsubsection{Vegetation inventory $\mathrm{S1}$}

This vegetation inventory is based on the study of Skjøth et al. (2008a). In order to prepare the inventory S1, a map of the area density of both conifers and broad-leaved trees is needed. We converted the land-cover categories of Globcover 2.2 using the factors given in Tab. Supp5 as described above (Eq. 7).

Then the detailed regional maps described in Skjøth et al. (2008a) were used to estimate the distribution of the vegetation types in the model domain: first, the original maps were reprojected from the EMEP50 Grid (http://www.emep. int/grid/griddescr.html) to our domain and then multiplied with the derived areas of conifers and broad-leaved trees. This yields the percentage of each of the vegetation types considered in each cell. This vegetation inventory contains 41 vegetation types (39 original ones plus agriculture and grass). Data is often given at the genus level (see Tab. Supp3). Note that this does not imply double counting. Assume that in one region S1 resolved between Quercus robur and Quercus suber, while in another region which in reality has the same tree-cover, just the genus Quercus sp. is indicated. This introduces uncertainty about the actual tree species, but it does not mean that trees are counted twice.

When the text refers to $\mathrm{S} 1$, only biomass seasonality is applied $\left(C_{\mathrm{s}}=1.0\right)$. 


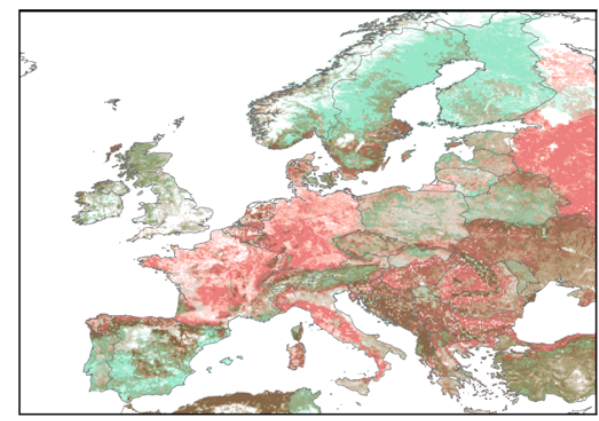

(a) S1

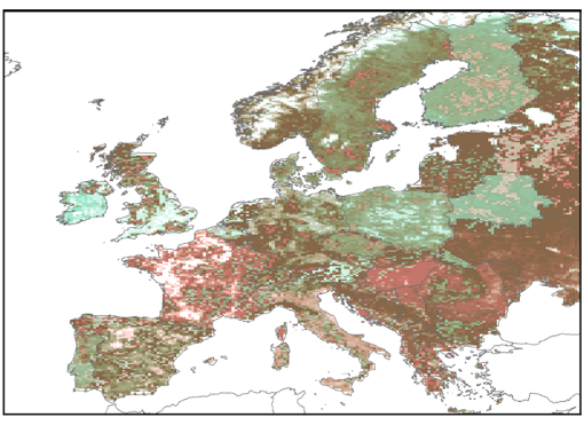

(b) S2

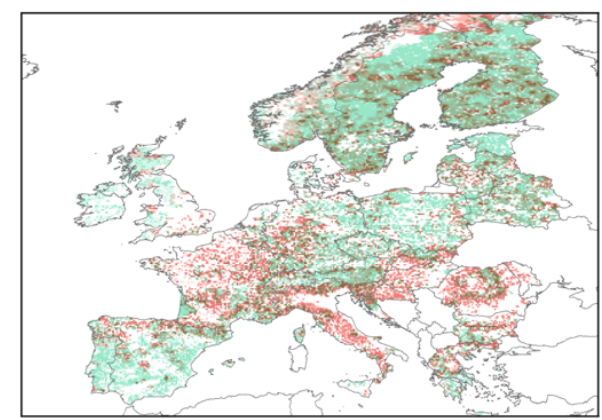

(c) $\mathrm{S} 3$

Fig. 4. False colour image of tree distribution of the three major inventories. Green channel: density of evergreen species, Red channel: density of deciduous species. The intensity of the colour is proportional to the fraction of the cell area covered by the given tree type, brown colours indicate mixed forests.

\subsubsection{Vegetation inventory $\mathrm{S} 2$}

The second vegetation inventory prepared in this work is based on the approach given by Simpson et al. (1999) that delivers a national estimate of species distribution of $32 \mathrm{veg}$ etation types (Tab. Supp3) in Europe by using statistical input at national scale for 37 countries. However, because at the time data for the Balkans was sparse, this region is represented only coarsely (Simpson et al., 1999).

In the case of this inventory, a map of the area density of forests is needed, therefore the factors $f_{c}$ differ from the ones for $\mathrm{S} 1$ for the mixed forest classes (Tab. Supp5). Although the approach is similar to the one in S1, in S2 the regions are the countries and the percentages are given as forest fractions.

When the text refers to $\mathrm{S} 2$, only biomass seasonality is applied $\left(C_{\mathrm{s}}=1.0\right)$.

\subsubsection{Vegetation inventory $\mathrm{S3}$}

This vegetation inventory was prepared by Köble and Seufert (2001), based on data of the ICP-forest network UN-ECE (UN-ECE, 1998). We only modified the projection from the original Lambert Azimuthal to Equirectangular projection and resolution from $1 \times 1 \mathrm{~km}$ to $0.25 \times 0.125^{\circ}$ by means of ArcGIS 10 by ESRI (http://www.esri.com/ software/arcgis/arcgis 10). This vegetation inventory has the highest thematic resolution of which we use 119 vegetation types. Most data of S3 is given at the species level. Only for some trees, data is available at the genus level.

Inventory S3 only covers parts of the CAMx model domain, due to the fact that it was compiled mainly for EU countries. We therefore use the terms "original countries" (the countries in which a given vegetation inventory is defined) and "common countries" (the set of countries that are common to all three vegetation inventories considered here) while comparing the tree inventories. In the "common countries" we exclude these countries: Albania, Algeria, Bosnia and Herzegovina, Cyprus, Kosovo, Macedonia, Malta, Montenegro, Morocco, Russian Federation, Serbia, Tunisia, Turkey and Ukraine.

When the text refers to $\mathrm{S} 3$, only biomass seasonality is applied $\left(C_{\mathrm{s}}=1.0\right)$.

\subsubsection{Comparison of vegetation inventories}

The total forest area covered by the three inventories is listed in Tab. Supp6. For comparison, the corresponding areas from Skjøth et al. (2008a) and Simpson et al. (1999) are indicated. The original data set created by Skjøth et al. (2008a) was based on GLC2000 and used land-cover correction factors $f_{c}$ of 1.0 (see Eq. 7). The table shows that S1, which is based on the same regional data but Globcover 2.2 does not agree 


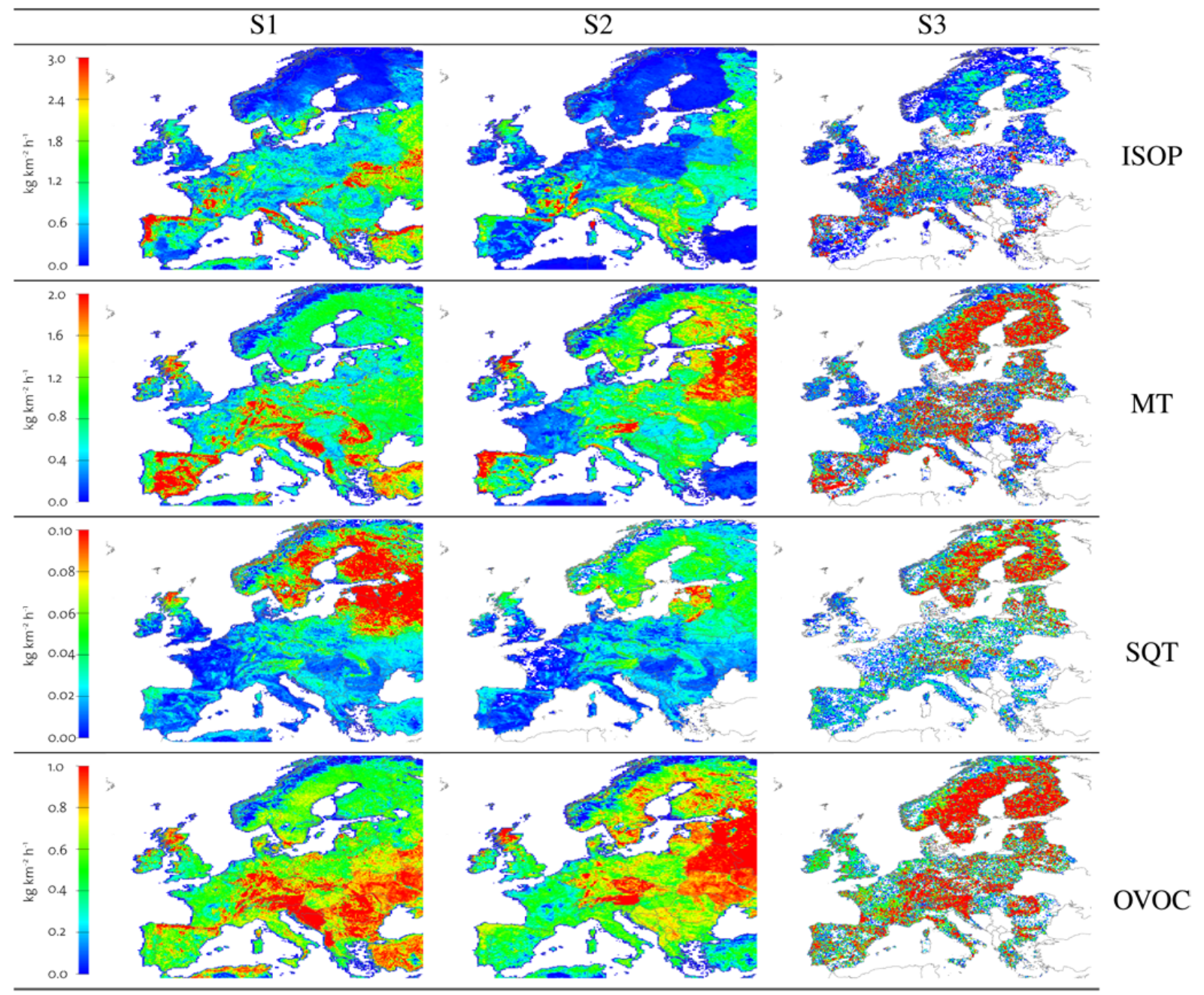

Fig. 5. Standard emission potentials SEP at $T=30^{\circ}$ and PAR $=1000 \mu \mathrm{molm} \mathrm{m}^{-2} \mathrm{~s}^{-1}$.

with the original data set for many countries. The same is true for S2, which can be compared to the data by Simpson et al. (1999) on which it is based. In Sect. 3.4 we will discuss the influence of the underlying land-cover inventory to the emissions. The differences are mostly due to differences in the underlying land-cover database which are caused by uncertainties in the land-cover classification.

The tree distribution of the inventories $\mathrm{S} 1$ to $\mathrm{S} 3$ is shown as a false-colour image in Fig. 4 where the intensity of the green channel is proportional to the fraction of evergreen trees in each pixel (grid cell) and the red channel is proportional to the fraction of the deciduous trees. Since S3 has the highest thematic resolution, the areas covered by the individual vegetation types are usually smaller than in the other inventories, where species have been lumped.

In general, tree density is higher in S1 and S2 than in S3. However, the distribution of the trees is less smooth in S3, which causes this vegetation inventory to look more "speckled". This is reflected in the relative standard devia- tions $\left(\mathrm{RSD}=\frac{s}{\bar{x}}\right)$ of the total tree-cover in each cell of the inventories. S3 has an RSD of $140 \%$, while S1 and S2 have an RSD of $75 \%$ and $72 \%$, respectively.

\subsubsection{Standard emission potential (SEP)}

Using the tree densities, we can directly derive the potential of the vegetation for BVOC emissions in Europe. We define the standard emission potential (SEP) for compound $j$ as follows:

$\mathrm{SEP}_{j}=\sum A_{i} \times D_{i} \times e_{0, j, i}$

where $i, A_{i}, D_{i}$ and $e_{0}$ are the same parameters as defined in Sect. 2.3.

The fields thus calculated indicate the emissions that would result at standard conditions $T=30^{\circ}$ and PAR $=1000 \mu \mathrm{mol} \mathrm{m}^{-2} \mathrm{~s}^{-1}$, neglecting corrections for seasonality. Fig. 5 shows the standard emission potentials for each compound and vegetation inventory in Europe. The standard 


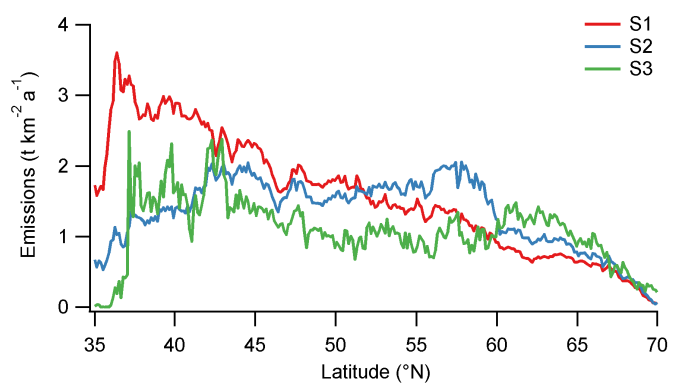

(a)

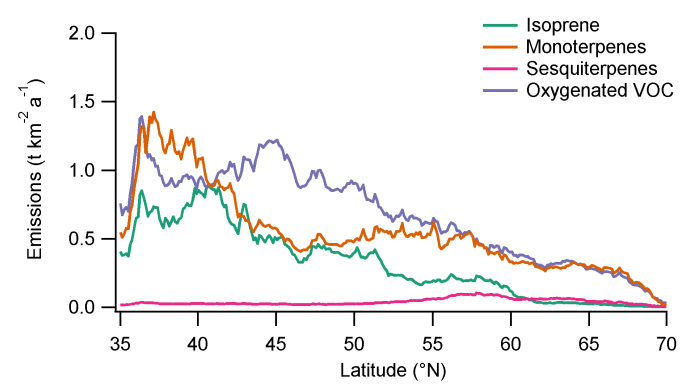

(b)

Fig. 6. Variation of annual emissions of 2006 for the original countries with latitude for the inventories (a) and variation of emissions of individual compounds in the S1 inventory with latitude (b).

emission potential for Northwest Africa and Turkey in S2 refer to agriculture and grass since there are no trees for these regions in inventory $\mathrm{S} 2$.

When the standard emission potential of the tree inventories (Fig. 5) is compared, the general spatial distribution of the emissions is similar due to the fact that both use the same definition of forests based on Globcover 2.2. The inventory S3, however, has a fundamentally different distribution due to the different approach based on the interpolation of 5513 sample plots in 30 European countries (Köble and Seufert, 2001).

\section{Results and discussion}

Here we present the main results in relation to the overall objective of the study. These results are grouped into five main sections: (a) continental scale BVOC modelling results; (b) BVOC modelling results in different European climatic regions and countries; (c) seasonal and daily variation of BVOC emissions; (d) sensitivity of BVOC emissions to temperature and the three land-cover data sets Globcover 2.2, GCL2000 and USGS GLCC; (e) comparison of measured ambient ISOP and MT concentrations with concentrations modelled using our BVOC emission model and the CAMx air quality model. As already discussed in section 2.3.1, the uncertainty of the basal emission rates for SQT and OVOC are higher than for ISOP and MT, this uncertainty enters the expression for the total emissions in a linear fashion.

\subsection{Continental scale BVOC modelling results}

The total annual emissions of each BVOC compound for all three tree inventories are shown at the bottom of Tab. 1. S1 has the highest emissions for all compounds when emissions are calculated on the basis of original data (original countries). When the emissions are calculated only in the common countries, the emissions by $\mathrm{S} 1$ exceed the other inventories for all compounds except MT, where S2 and S3 have emissions exceeding $\mathrm{S} 1$. The range of the annual emissions for the original countries is $3571-5328 \mathrm{Gg} \mathrm{yr}^{-1}$ for OVOC,
2964-4124 $\mathrm{Gg} \mathrm{yr}^{-1}$ for MT, 1462-2650 $\mathrm{Gg} \mathrm{yr}^{-1}$ for ISOP and $150-257 \mathrm{Gg} \mathrm{yr}^{-1}$ for SQT. The latitudinal gradient of the emissions due to the three inventories differs considerably (Fig. 6), illustrating the fact that even if the monthly totals are similar, the spatial distribution differs. S1 has a clear negative trend with increasing latitude (higher than about $36^{\circ} \mathrm{N}$ ), which is accentuated by the fact that this is the only inventory where Northwest Africa contributes substantially. The latitudinal gradient for S2 is smoother due to its large regions, with a maximum at $57^{\circ} \mathrm{N}$. S3, on the other hand shows high values in the south (in the band between $37^{\circ} \mathrm{N}$ and $44^{\circ} \mathrm{N}$ ) and then again increased values at latitudes around $60^{\circ} \mathrm{N}$. Considering the composition of the emissions of S1, the gradients differ as well (Fig. 6b). OVOC show a similar negative trend like the total emissions of S1. OVOC can be seen as a tracer for forest density and temperature because most of the vegetation types have a basal emission rate of $2 \mu \mathrm{gh}^{-1} \mathrm{~g}_{\mathrm{dw}}^{-1}$. Notable exceptions are Fagus sylvatica (European Beech) with $10 \mu \mathrm{gh}^{-1} \mathrm{~g}_{\mathrm{dw}}^{-1}$ and Quercus ilex (Evergreen Holm oak) with $4.08 \mu \mathrm{gh}^{-1} \mathrm{~g}_{\mathrm{dw}}^{-1}$ (Tab. Supp3). MT show a pronounced peak centred around $38^{\circ} \mathrm{N}$ which can be attributed mostly to the evergreen oaks and conifers in North West Africa and the Iberian Peninsula. Then, centred around $55^{\circ} \mathrm{N}$ a broader and weaker peak is visible, this is mostly due to Fagus sylvatica with a high emission factor for MTS emission $\left(21.14 \mu \mathrm{gh}^{-1} \mathrm{~g}_{\mathrm{dw}}^{-1}\right)$. ISOP shows a similar trend like OVOC, only that the highest peak of ISOP is at higher latitudes (around $41^{\circ} \mathrm{N}$ ), which is the latitude of the Northern part of the Iberian Peninsula. SQT are at a much lower level than the other compounds, with slightly increasing emissions in latitudes higher than $52^{\circ} \mathrm{N}$. This is mostly due to the increased density of Betula sp. in the boreal zone, with their high emission factor of $2 \mu \mathrm{g} \mathrm{h}^{-1} \mathrm{~g}_{\mathrm{dw}}^{-1}$, compared to the default emission factor for SQT of $0.1 \mu \mathrm{gh}^{-1} \mathrm{~g}_{\mathrm{dw}}^{-1}$.

On the tree species level, some trees are especially interesting. For example, the neophyte Eucalyptus sp. covers only an area of about $12600 \mathrm{~km}^{2}$ (in S3), which is about $0.24 \%$ of the landmass covered by S3, but it is predicted to produce $17 \%$ of the annual ISOP and $2 \%$ of the annual MT for 


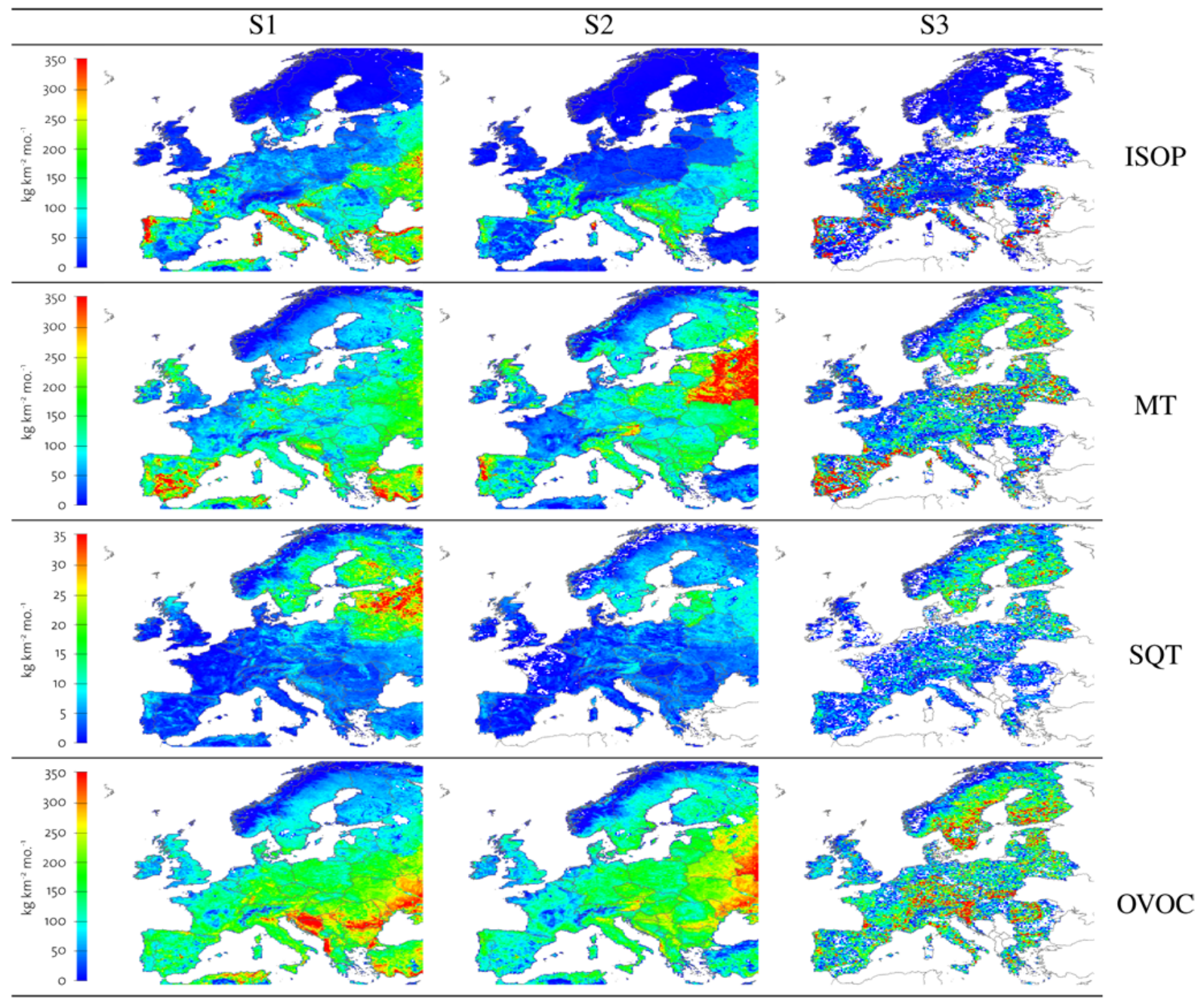

Fig. 7. Total Emissions in June 2006 for the inventories S1-S3.

inventory S3 due to the large emission factors and favourable conditions. This illustrates that even minor species may have a large influence on BVOC emissions and stresses the need for highly resolved tree inventories. Eucalyptus sp. is a case where the inventories differ strongly: in S1 and S2 Eucalyptus sp. only produce $3 \%$ of the annual ISOP emissions. Eucalyptus sp. is a fast-growing tree that is planted commercially and harvested within a few years, therefore it is possible that the plantation pattern changes rapidly (Street et al., 1997). On the other hand, trees of the genus Quercus sp. clearly dominate the European ISOP emissions both because they are common and have high emission factors. Depending on the inventories, oaks produce $69 \%$ (S1), $51 \%$ (S2) and $64 \%$ (S3) of the annual biogenic ISOP in Europe.

We have determined the top ten emitting vegetation types for the three inventories (Tabs. 2 to 5) on an annual basis. The top ten vegetation types with respect to emissions explain a high fraction of the total emissions. The fraction of the annual emissions contributed by the top emitters is 92
$97 \%, 82-93 \%, 90-95 \%$ and $89-96 \%$ for ISOP, MT, SQT and OVOCs, respectively (Tables 2-5).

The contribution of the vegetation type "agriculture" is significant but varies with the vegetation inventory: 3-14\% of the annual ISOP emissions, 3-12\% of the annual emissions of MT and 7-27\% of the annual OVOC emissions are due to "agriculture" (the reference emission factor of "agriculture" for SQT is zero).

\subsection{BVOC modelling results in different European climatic regions and countries}

This section discusses BVOC modelling results in different climatic zones and these regions in the model domain: Northwest Africa, Central Europe, The Iberian Peninsula, The Balkan Peninsula, Scandinavia, Italy, British Isles, Baltic States and the Benelux countries. Emissions for these regions are compared in Tab. 7 and emissions in June and January 2006 are shown in Figs. 7 and Supp6, respectively. 
Table 1. Emission data by country (annual totals in $\mathrm{Gg} \mathrm{yr}^{-1}$ ) and overall totals. Common countries are marked with *, these are the countries that are contained in all vegetation inventories (S1-S3). Some cells are not assigned to a country, these are mostly shore cells.

\begin{tabular}{|c|c|c|c|c|c|c|c|c|c|c|c|c|}
\hline \multirow[t]{2}{*}{ Country } & \multicolumn{4}{|c|}{ S1 } & \multicolumn{4}{|c|}{$\mathrm{S} 2$} & \multicolumn{4}{|c|}{ S3 } \\
\hline & ISOP & MT & SQT & OVOC & ISOP & MT & SQT & OVOC & ISOP & MT & SQT & OVOC \\
\hline Albania & 16 & 34 & 1 & 54 & 25 & 21 & 1 & 33 & N/A & N/A & N/A & N/A \\
\hline Algeria & 105 & 125 & 4 & 171 & 13 & 32 & 0 & 80 & N/A & N/A & N/A & N/A \\
\hline Austria* & 10 & 32 & 3 & 82 & 16 & 91 & 3 & 87 & 8 & 38 & 4 & 104 \\
\hline Belarus* & 49 & 130 & 18 & 160 & 30 & 306 & 7 & 222 & 17 & 138 & 8 & 116 \\
\hline Belgium* & 11 & 8 & 1 & 18 & 3 & 20 & 1 & 19 & 10 & 10 & 0 & 21 \\
\hline Bosnia \& Herz. & 19 & 46 & 2 & 108 & 37 & 34 & 1 & 51 & N/A & N/A & N/A & N/A \\
\hline Bulgaria* & 60 & 87 & 3 & 154 & 55 & 105 & 3 & 104 & 75 & 58 & 2 & 78 \\
\hline Croatia* & 40 & 35 & 2 & 81 & 32 & 31 & 1 & 49 & 28 & 19 & 1 & 41 \\
\hline Czech Republic* & 24 & 42 & 3 & 86 & 11 & 37 & 3 & 94 & 13 & 40 & 3 & 84 \\
\hline Denmark* & 8 & 12 & 1 & 24 & 3 & 12 & 0 & 22 & 3 & 6 & 0 & 13 \\
\hline Estonia* & 5 & 17 & 5 & 21 & 3 & 42 & 3 & 31 & 2 & 32 & 2 & 39 \\
\hline Finland* & 8 & 105 & 23 & 104 & 4 & 145 & 9 & 157 & 11 & 230 & 20 & 276 \\
\hline France* & 226 & 207 & 7 & 369 & 228 & 123 & 5 & 247 & 277 & 275 & 12 & 411 \\
\hline Germany* & 79 & 197 & 9 & 299 & 35 & 149 & 8 & 256 & 36 & 159 & 9 & 294 \\
\hline Greece* & 99 & 74 & 3 & 91 & 78 & 68 & 3 & 88 & 98 & 66 & 3 & 71 \\
\hline Hungary* & 51 & 46 & 2 & 89 & 52 & 37 & 1 & 72 & 38 & 19 & 1 & 33 \\
\hline Ireland* & 4 & 43 & 1 & 37 & 3 & 30 & 1 & 35 & 3 & 32 & 0 & 36 \\
\hline Italy* & 201 & 150 & 6 & 254 & 104 & 201 & 5 & 204 & 131 & 127 & 5 & 193 \\
\hline Kosovo & 3 & 4 & 0 & 9 & N/A & N/A & N/A & N/A & N/A & N/A & N/A & N/A \\
\hline Latvia* & 10 & 27 & 8 & 34 & 9 & 66 & 4 & 53 & 5 & 41 & 4 & 54 \\
\hline Lithuania* & 11 & 23 & 4 & 35 & 4 & 33 & 4 & 43 & 4 & 33 & 3 & 38 \\
\hline Luxembourg* & 1 & 1 & 0 & 2 & 1 & 2 & 0 & 2 & 1 & 1 & 0 & 3 \\
\hline Macedonia & 12 & 13 & 1 & 25 & 18 & 16 & 1 & 24 & N/A & N/A & N/A & N/A \\
\hline Moldova* & 21 & 23 & 1 & 40 & 15 & 25 & 1 & 40 & 12 & 1 & 0 & 3 \\
\hline Montenegro & 3 & 4 & 0 & 10 & N/A & N/A & N/A & N/A & N/A & N/A & N/A & N/A \\
\hline Morocco & 6 & 7 & 0 & 11 & 1 & 3 & 0 & 8 & N/A & N/A & N/A & N/A \\
\hline Netherlands* & 10 & 10 & 1 & 17 & 2 & 13 & 0 & 15 & 9 & 11 & 0 & 20 \\
\hline Norway* & 8 & 31 & 7 & 52 & 5 & 81 & 5 & 61 & 5 & 69 & 9 & 110 \\
\hline Poland* & 66 & 162 & 10 & 225 & 30 & 213 & 8 & 222 & 47 & 209 & 9 & 205 \\
\hline Portugal* & 115 & 104 & 3 & 81 & 54 & 118 & 2 & 77 & 126 & 147 & 4 & 83 \\
\hline Romania* & 76 & 119 & 5 & 297 & 85 & 136 & 5 & 198 & 55 & 56 & 3 & 163 \\
\hline Russian Fed. & 135 & 294 & 46 & 255 & 113 & 593 & 17 & 459 & N/A & N/A & N/A & N/A \\
\hline Serbia & 28 & 37 & 2 & 86 & N/A & N/A & N/A & N/A & N/A & N/A & N/A & N/A \\
\hline Slovakia* & 15 & 16 & 1 & 36 & 12 & 15 & 1 & 38 & 12 & 20 & 1 & 47 \\
\hline Slovenia* & 7 & 11 & 1 & 29 & 11 & 10 & 0 & 14 & 5 & 14 & 1 & 34 \\
\hline Spain* & 249 & 637 & 12 & 447 & 117 & 326 & 8 & 325 & 305 & 648 & 12 & 358 \\
\hline Sweden* & 37 & 120 & 24 & 180 & 9 & 147 & 15 & 223 & 26 & 273 & 26 & 417 \\
\hline Switzerland* & 4 & 10 & 1 & 27 & 2 & 9 & 1 & 23 & 3 & 11 & 1 & 30 \\
\hline Tunisia & 20 & 56 & 1 & 54 & 4 & 11 & 0 & 28 & N/A & N/A & N/A & N/A \\
\hline Turkey & 391 & 480 & 13 & 445 & 30 & 72 & 0 & 178 & N/A & N/A & N/A & N/A \\
\hline Ukraine & 330 & 300 & 14 & 490 & 186 & 308 & 11 & 481 & N/A & N/A & N/A & N/A \\
\hline United Kingdom* & 18 & 132 & 5 & 123 & 17 & 152 & 3 & 122 & 22 & 91 & 2 & 106 \\
\hline Unassigned & 60 & 112 & 5 & 121 & 70 & 74 & 6 & 134 & 73 & 93 & 4 & 94 \\
\hline Tot. original count. & 2650 & 4124 & 257 & 5328 & 1528 & 3906 & 147 & 4618 & 1462 & 2964 & 150 & 3571 \\
\hline Tot. common count. & 1521 & 2611 & 166 & 3491 & 1030 & 2742 & 111 & 3142 & 1389 & 2871 & 146 & 3477 \\
\hline
\end{tabular}

The annual emissions in Gg by climatic zone are shown in Tabs. Supp7 and Supp8 for the original and the common countries, respectively. When comparing the emissions on a zone-by-zone basis for the countries common to all inventories (Tab. Supp8), the relative differences between the inventories (taking S1 as the reference) is in the range of $-59 \%$ (MT in the "arid" zone of S2) to +97\% (OVOC in the "cold with cold summer" zone of S3).
Over most of the regions discussed below, the most important species are similar between inventories, but their spatial distribution varies. This cannot be seen in the totals but is highly important for 3-D air quality modelling. This is crucial in proximity of large cities with strong anthropogenic emissions. For example, the inventories differ strongly close to Paris - S1 predicts strong ISOP emissions about $100 \mathrm{~km}$ south of Paris, while in S3, emissions of a similar magnitude occur already at a distance of about $40 \mathrm{~km}$ while in S2, 
Table 2. Top emitters of isoprene (based on annual data, original countries), selected so that at least the ten most important emitters

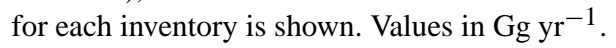

\begin{tabular}{lrrr}
\hline & \multicolumn{1}{c}{$\mathrm{S} 1$} & \multicolumn{1}{c}{$\mathrm{S} 2$} & \multicolumn{1}{c}{$\mathrm{S} 3$} \\
\hline Quercus sp. & $1024(39 \%)$ & $546(36 \%)$ & $\mathrm{N} / \mathrm{A}$ \\
Quercus robur & $466(18 \%)$ & $104(07 \%)$ & $281(22 \%)$ \\
Populus sp. & $278(10 \%)$ & $73(05 \%)$ & $\mathrm{N} / \mathrm{A}$ \\
Agriculture & $215(08 \%)$ & $211(14 \%)$ & $38(03 \%)$ \\
Quercus pubescens & $166(06 \%)$ & $36(02 \%)$ & $174(14 \%)$ \\
Quercus petraea & $98(04 \%)$ & $53(03 \%)$ & $140(11 \%)$ \\
Eucalyptus sp. & $86(03 \%)$ & $48(03 \%)$ & $214(17 \%)$ \\
Quercus faginea & $83(03 \%)$ & $41(03 \%)$ & $52(04 \%)$ \\
Other broadleaves & $65(02 \%)$ & $91(06 \%)$ & $\mathrm{N} / \mathrm{A}$ \\
Grassland & $53(02 \%)$ & $52(03 \%)$ & $30(02 \%)$ \\
Picea sp. & $34(01 \%)$ & $127(08 \%)$ & $\mathrm{N} / \mathrm{A}$ \\
Picea abies & $34(01 \%)$ & $39(03 \%)$ & $58(05 \%)$ \\
Quercus frainetto & $\mathrm{N} / \mathrm{A}$ & $\mathrm{N} / \mathrm{A}$ & $87(07 \%)$ \\
Quercus pyrenaica & N/A & N/A & $61(05 \%)$ \\
Unknown & N/A & $79(05 \%)$ & N/A \\
\hline Total & $2603(98 \%)$ & $1501(98 \%)$ & $1134(90 \%)$ \\
\hline
\end{tabular}

Table 3. Top emitters of monoterpenes (based on annual data, original countries), selected so that at least the ten most important emitters for each inventory is shown. Values in $\mathrm{Gg} \mathrm{yr}^{-1}$.

\begin{tabular}{lrrr}
\hline & S1 & \multicolumn{1}{c}{$\mathrm{S} 2$} & \multicolumn{1}{c}{$\mathrm{S} 3$} \\
\hline Pinus sylvestris & $712(17 \%)$ & $725(19 \%)$ & $1145(40 \%)$ \\
Agriculture & $512(12 \%)$ & $478(12 \%)$ & $96(03 \%)$ \\
Pinus sp. & $455(11 \%)$ & $722(18 \%)$ & $\mathrm{N} / \mathrm{A}$ \\
Fagus sylvatica & $305(07 \%)$ & $\mathrm{N} / \mathrm{A}$ & $147(05 \%)$ \\
Quercus ilex & $269(07 \%)$ & $170(04 \%)$ & $368(13 \%)$ \\
Quercus sp. & $264(06 \%)$ & $134(03 \%)$ & $\mathrm{N} / \mathrm{A}$ \\
Betula sp. & $254(06 \%)$ & $39(<1 \%)$ & $\mathrm{N} / \mathrm{A}$ \\
Picea sp. & $238(06 \%)$ & $833(21 \%)$ & $\mathrm{N} / \mathrm{A}$ \\
Pinus nigra & $179(04 \%)$ & $8(<1 \%)$ & $91(03 \%)$ \\
Picea abies & $159(04 \%)$ & $177(05 \%)$ & $301(10 \%)$ \\
Picea sitchensis & $151(04 \%)$ & $120(03 \%)$ & $100(03 \%)$ \\
Grassland & $143(03 \%)$ & $134(03 \%)$ & $100(03 \%)$ \\
Pinus pinaster & $40(<1 \%)$ & $53(01 \%)$ & $84(03 \%)$ \\
Eucalyptus sp. & $27(<1 \%)$ & $15(<1 \%)$ & $72(02 \%)$ \\
Unknown & $\mathrm{N} / \mathrm{A}$ & $108(03 \%)$ & $\mathrm{N} / \mathrm{A}$ \\
\hline Total & $3707(90 \%)$ & $3714(95 \%)$ & $2502(86 \%)$ \\
\hline
\end{tabular}

the distance is similar as in S1 (due to the same underlying land-cover), but the magnitude of the emission is smaller than in S1 (due to the "dilution" effect of the larger regions over which tree species are defined).

Northwest Africa is only covered by S1, where a clear distinction between Tunisia (mostly evergreen trees - predominantly Quercus suber) and Algeria (mixed forests of Quercus ilex (evergreen broad-leaved trees) and conifers of the genus Pinus sp.) is seen in the inventory, which is consistent with literature (Merlo and Croitoru, 2005). Since average June temperatures in Northwest Africa are between $27^{\circ} \mathrm{C}$
Table 4. Top emitters of sesquiterpenes (based on annual data, original countries), selected so that at least the ten most important emitters for each inventory is shown. Values in $\mathrm{Gg} \mathrm{yr}^{-1}$.

\begin{tabular}{lrrr}
\hline & S1 & \multicolumn{1}{c}{$\mathrm{S} 2$} & \multicolumn{1}{c}{$\mathrm{S} 3$} \\
\hline Betula sp. & $147(57 \%)$ & $25(17 \%)$ & $\mathrm{N} / \mathrm{A}$ \\
Betula pubescens & $\mathrm{N} / \mathrm{A}$ & $\mathrm{N} / \mathrm{A}$ & $28(17 \%)$ \\
Betula pendula & $\mathrm{N} / \mathrm{A}$ & $\mathrm{N} / \mathrm{A}$ & $17(11 \%)$ \\
Picea abies & $20(08 \%)$ & $25(17 \%)$ & $45(28 \%)$ \\
Pinus sylvestris & $19(07 \%)$ & $22(15 \%)$ & $36(22 \%)$ \\
Pinus sp. & $9(04 \%)$ & $16(11 \%)$ & $\mathrm{N} / \mathrm{A}$ \\
Quercus sp. & $9(03 \%)$ & $5(04 \%)$ & $\mathrm{N} / \mathrm{A}$ \\
Fagus sylvatica & $7(03 \%)$ & $\mathrm{N} / \mathrm{A}$ & $4(02 \%)$ \\
Picea sp. & $7(03 \%)$ & $26(18 \%)$ & $\mathrm{N} / \mathrm{A}$ \\
Other broadleaves & $4(02 \%)$ & $5(04 \%)$ & $\mathrm{N} / \mathrm{A}$ \\
Pinus nigra & $4(02 \%)$ & $0(<1 \%)$ & $2(01 \%)$ \\
Pinus halepensis & $4(01 \%)$ & $1(<1 \%)$ & $2(01 \%)$ \\
Other conifers & $3(01 \%)$ & $3(02 \%)$ & $\mathrm{N} / \mathrm{A}$ \\
Abies alba & $2(<1 \%)$ & $\mathrm{N} / \mathrm{A}$ & $3(02 \%)$ \\
Fagus sp. & $2(<1 \%)$ & $4(03 \%)$ & $\mathrm{N} / \mathrm{A}$ \\
Pinus pinaster & $2(<1 \%)$ & $3(02 \%)$ & $4(03 \%)$ \\
Quercus ilex & $2(<1 \%)$ & $1(<1 \%)$ & $3(02 \%)$ \\
Unknown & $\mathrm{N} / \mathrm{A}$ & $3(02 \%)$ & $\mathrm{N} / \mathrm{A}$ \\
\hline Total & $240(94 \%)$ & $140(95 \%)$ & $144(90 \%)$ \\
\hline
\end{tabular}

Table 5. Top emitters of OVOC (based on annual data, original countries), selected so that at least the ten most important emitters

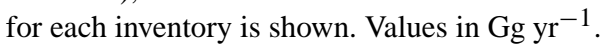

\begin{tabular}{lrrr}
\hline \multicolumn{1}{c}{$\mathrm{S} 1$} & \multicolumn{1}{c}{$\mathrm{S} 2$} & \multicolumn{1}{c}{$\mathrm{S} 3$} \\
\hline Agriculture & $1295(24 \%)$ & $1239(27 \%)$ & $233(07 \%)$ \\
Fagus sylvatica & $807(15 \%)$ & $\mathrm{N} / \mathrm{A}$ & $393(12 \%)$ \\
Picea abies & $552(10 \%)$ & $634(14 \%)$ & $1032(30 \%)$ \\
Pinus sylvestris & $461(09 \%)$ & $487(11 \%)$ & $723(21 \%)$ \\
Grassland & $388(07 \%)$ & $372(08 \%)$ & $278(08 \%)$ \\
Pinus sp. & $221(04 \%)$ & $363(08 \%)$ & N/A \\
Quercus sp. & $217(04 \%)$ & $115(02 \%)$ & N/A \\
Picea sp. & $199(04 \%)$ & $715(15 \%)$ & N/A \\
Betula sp. & $178(03 \%)$ & $28(<1 \%)$ & N/A \\
Pinus nigra & $93(02 \%)$ & $4(<1 \%)$ & $46(01 \%)$ \\
Other broadleaves & $93(02 \%)$ & $122(03 \%)$ & N/A \\
Fagus sp. & $43(<1 \%)$ & $89(02 \%)$ & N/A \\
Other conifers & $81(02 \%)$ & $77(02 \%)$ & N/A \\
Quercus ilex & $82(02 \%)$ & $56(01 \%)$ & $109(03 \%)$ \\
Pinus pinaster & $42(<1 \%)$ & $57(01 \%)$ & $84(02 \%)$ \\
Abies alba & $59(01 \%)$ & N/A & $58(02 \%)$ \\
Picea sitchensis & $71(01 \%)$ & $58(01 \%)$ & $45(01 \%)$ \\
\hline Total & $4883(92 \%)$ & $4416(96 \%)$ & $3002(89 \%)$ \\
\hline
\end{tabular}

and $30{ }^{\circ} \mathrm{C}$ (Fig. Supp7), the high standard emission potentials (Fig. 5) are reflected in high emissions in June 2006 (Fig. 7) with high emissions of OVOC, MT and ISOP.

The forests in Central Europe are dominated by Quercus sp. and Fagus sylvatica, followed by Pinus sylvestris and Picea abies. The strongest differences between the 
Table 6. Total emissions in $\mathrm{Gg} \mathrm{mo}^{-1}$ for January and June 2006 (common countries).

\begin{tabular}{|c|c|c|c|c|c|c|c|c|}
\hline & \multicolumn{4}{|c|}{ January } & \multicolumn{4}{|c|}{ June } \\
\hline & ISOP & MT & SQT & OVOC & ISOP & MT & SQT & OVOC \\
\hline S1 & 4 & 24 & 2 & 34 & 334 & 495 & 29 & 637 \\
\hline S2 & 2 & 23 & 1 & 27 & 230 & 518 & 19 & 591 \\
\hline S3 & 4 & 25 & 1 & 38 & 294 & 532 & 25 & 594 \\
\hline
\end{tabular}

inventories are in ISOP, where S1 emits $19 \%$ more than S2 (mostly due to the density of Quercus sp.) and in MT, where S3 emits $8 \%$ more than $\mathrm{S} 1$ (mostly due to a higher density of Pinus sylvestris).

The Iberian Peninsula has total BVOC emissions close to central Europe in all inventories due to the relatively high temperatures and the presence of important emitters. Comparing the areas of these it follows that the average annual BVOC emissions are about a factor of 1.8 higher in the Iberian Peninsula $\left(2.8 \mathrm{tm}^{-2} \mathrm{a}^{-1}\right)$ than in Central Europe $\left(1.6 \mathrm{t} \mathrm{m}^{-2} \mathrm{a}^{-1}\right)$, indicating the need for research on detailed BVOC emission assessments on the Iberian Peninsula. The tree vegetation of this region differs significantly from other regions in Europe because of common evergreen broadleaved species such as Eucalyptus sp. or Quercus ilex. Eucalyptus sp. is a strong ISOP and a rather strong emitter of MT, while Quercus ilex is a weak ISOP but a strong emitter of MT (see also Tab. Supp3). The emission pattern is comparable in S1 and S3, with generally (except for OVOC) higher and more concentrated emissions in S3. In S2, the countrywise approach leads to a smearing of the species - both Spain and Portugal show a uniform (but distinct) colour in the false colour image.

In the Balkan Peninsula, many countries are not common to all inventories, so it is difficult to compare the tree distribution. In the following discussion, we refer to the countries for which all inventories provide data (Bulgaria, Croatia, Greece, Romania, Slovenia). In all inventories, agriculture and grass are predicted to be important land-cover categories in this region. The annual emissions are similar for all inventories, except that S3 predicts $41 \%$ less OVOC, $35 \%$ less MT and $21 \%$ less SQT than S1.

Most of Scandinavia is dominated by a boreal climate and hence shows the typical vegetation mostly with conifers and birches (Betula sp.). Most notably, Betula pendula shows high emissions of SQT with an emission factor that is 20 times higher than the default factor (Hakola et al., 2001; Steinbrecher et al., 2009). The conifers are important MT emitters, a feature that is clearly visible in the standard emission potential of inventory S3 (Fig. 5). In S1, the emissions of SQT are the most prominent feature of this region, while in S2, neither MT nor SQT are predicted to be very important.

Italy shows diverse ecologic habitats with alpine and temperate character in the north and mediterranean character in the south. Such a country is difficult to describe in terms of
S2, where all the forests of a country have the same composition, especially since the data given in Simpson et al. (1999) shows $58 \%$ of uncategorised trees. In such a case, the resulting emissions critically depend on the parameters given to this category (refer to the end of Tab. Supp3 for this data). In all inventories, agriculture is predicted to be an important land-cover category for Italy ( $24 \%$ in S1 and S2, $8 \%$ in S3). Here, the differences between the inventories are largest for ISOP with S2 predicting $48 \%$ less than S1 and S3 35\% less than S1.

The diversity of the vegetation of the British Isles is relatively small, which is captured by all inventories. The most abundant tree species are of the genus Picea sp., most notably Picea sitchensis and Picea abies. A recent, very detailed study on the British vegetation (Stewart et al., 2008) showed that Picea sitchensis is the most abundant tree species in Great Britain. The largest difference between the inventories occurs in SQT where S3 produces $63 \%$ less than S1 and S2 $34 \%$ less than $\mathrm{S} 1$. This is because $\mathrm{S} 1$ predicts a higher density of trees in Scotland than S3. For the British Isles it was pointed out by Skjøth et al. (2008a) that a number of species such as Betula sp., Fraxinus sp. and Pseudotsuga sp. were not present in S3 although they were found in the national forest inventory. Here, Betula sp. is an important source of SQT.

The Baltic States, apart from agriculture have a similar forest vegetation as the Scandinavian Peninsula: S1 predicts Betula sp., Pinus sylvestris, Alnus sp. and Picea abies to be the dominating species. The predicted emissions of S1 are lower than for the other inventories. In the case of MT, S2 predicts $108 \%$ more and S3 $57 \%$ more than S1. This is because in S1, Betula sp. dominates while it is less important in the other two. This is also the reason why S1 predicts more SQT: S2 predicts $33 \%$ less and S3 $51 \%$ less of this compound than S1.

The Benelux countries (Belgium, the Netherlands, and Luxembourg) are dominated by agriculture and grassland. The annual totals show a similar pattern as in the case of the Baltic States: also here, S2 and S3 predict more MT (+83\% and $+18 \%$, respectively). Also, S1 produces more SQT than $\mathrm{S} 2$ and $\mathrm{S} 3$ here ( $25 \%$ and $37 \%$, respectively).

When comparing the total emissions by country (Tab. 8 , full data set in Tab. Supp1) with other publications such as (Simpson et al., 1999) (base year 1999) or (Karl et al., 2009) (base year 2005), we see that the differences both between the results by the other authors as well as between our scenarios are largest for Finland and Spain.

It is not surprising that the results of S2 are often close to the results of Simpson et al. (1999) and S3 to the results of Karl et al. (2009) because the respective vegetation inventories are related. 
Table 7. Annual total emissions in $\mathrm{Gg} \mathrm{yr}^{-1}$ in selected regions of Europe for 2006, ordered by total BVOC emissions projected by $\mathrm{S} 1$ (common countries).

\begin{tabular}{|c|c|c|c|c|c|c|c|c|c|c|c|c|}
\hline & \multicolumn{4}{|c|}{ S1 } & \multicolumn{4}{|c|}{ S2 } & \multicolumn{4}{|c|}{ S3 } \\
\hline & ISOP & MT & SQT & OVOC & ISOP & MT & SQT & OVOC & ISOP & MT & SQT & OVOC \\
\hline Central Europe $^{1}$ & 474 & 711 & 35 & 1211 & 385 & 673 & 29 & 1039 & 435 & 770 & 40 & 1207 \\
\hline Iberian Peninsula ${ }^{2}$ & 364 & 741 & 15 & 528 & 171 & 445 & 10 & 402 & 432 & 795 & 16 & 440 \\
\hline Balkan Peninsula ${ }^{3}$ & 281 & 327 & 13 & 651 & 262 & 349 & 12 & 452 & 261 & 213 & 10 & 387 \\
\hline Scandinavian Peninsula ${ }^{4}$ & 61 & 268 & 54 & 360 & 21 & 385 & 30 & 463 & 44 & 578 & 55 & 815 \\
\hline Italian Peninsula & 201 & 150 & 6 & 254 & 104 & 201 & 5 & 204 & 131 & 127 & 5 & 193 \\
\hline British Isles ${ }^{5}$ & 22 & 175 & 6 & 160 & 20 & 183 & 4 & 157 & 25 & 122 & 2 & 142 \\
\hline Baltic States $^{6}$ & 27 & 67 & 17 & 90 & 17 & 140 & 12 & 127 & 11 & 106 & 8 & 131 \\
\hline Benelux countries ${ }^{7}$ & 23 & 19 & 1 & 37 & 6 & 35 & 1 & 36 & 20 & 22 & 1 & 43 \\
\hline
\end{tabular}

${ }^{1}$ Austria, Czech Republic, Germany, France, Hungary, Poland, Slovakia, Switzerland

${ }^{2}$ Spain, Portugal

3 Bulgaria, Croatia, Greece, Romania, Slovenia

${ }^{4}$ Sweden, Norway, Finland, Denmark

${ }^{5}$ United Kingdom and the Republic of Ireland

${ }^{6}$ Estonia, Latvia, and Lithuania

7 Belgium, Netherlands, Luxembourg

Table 8. Comparison of total annual BVOC emissions $\left(\mathrm{Gg} \mathrm{yr}^{-1}\right)$ in different countries to literature data. Base years of Simpson et al. (1999), Karl et al. (2009) and Smiatek and Steinbrecher (2006) are 1999, 2005 and 1994-2003, respectively. Note that the vegetation inventories of Simpson et al. (1999) and S2 as well as Karl et al. (2009), Smiatek and Steinbrecher (2006) and S3 are related.

\begin{tabular}{llllrrr}
\hline & $\begin{array}{l}\text { Simpson et } \\
\text { al. (1999) }\end{array}$ & $\begin{array}{l}\text { Karl et } \\
\text { al. (2009) }\end{array}$ & $\begin{array}{l}\text { Smiatek and } \\
\text { Steinbrecher (2006) }\end{array}$ & S1 & S2 & S3 \\
\hline Finland & 355 & 577 & & 241 & 315 & 537 \\
Spain & 820 & 1042 & & 1345 & 776 & 1324 \\
Germany & 474 & 349 & 366 & 583 & 448 & 499 \\
United Kingdom & 178 & 219 & & 278 & 295 & 220 \\
\hline
\end{tabular}

\subsection{Seasonal and daily variation of BVOC emissions}

The yearly cycle of the emissions shows a characteristic sinusoidal behaviour (Figs. Supp8 and Supp9) which is governed mostly by irradiance and temperature. Without any seasonal correction (Fig. Supp10) the same pattern is present. The highest emissions occur in July, lowest in January-February for all three tree inventories. A large proportion of the difference between the monthly emission totals of three inventories in Fig. Supp9 can be explained by the difference in number of countries included in each vegetation inventory. When interpreting Fig. Supp8, however, we must consider that even if the totals are similar, the spatial distributions of the emissions predicted differ strongly.

When only the seasonality of the biomass is taken into account, annual OVOC emissions are reduced by -31 to $-32 \%$, MT by -25 to $-30 \%$, SQT by -20 to $-28 \%$ and is reduced by -19 to $-24 \%$. When in addition seasonality of enzymatic activity is taken into account, ISOP emissions are almost completely suppressed in the months January to March and October to December (Fig. Supp11). Also, the emissions of MT decrease slightly stronger than with sea- sonality of the biomass alone: ISOP is reduced by -44 to $-49 \%$ and MT by -30 and $-35 \%$.

If we compare the spatial distribution of the emissions in June (Fig. 7) and January (Fig. Supp6), it is quite similar for both months, except that in winter, emissions at latitudes higher than about $64^{\circ} \mathrm{N}$ drop markedly because of the increasing importance of Betula sp. which is deciduous and hence produces no emissions in winter. It has to be noted that the total amount of emitted BVOC is January is about a factor of 30 less than in June.

In terms of the total emissions for summer and winter (see Tab. 6), ISOP is most strongly reduced in winter by a factor of 65-100 due to the fact that most emitters are deciduous (no leaves in winter) and ISOP emissions are both light and temperature dependent. The difference between summer and winter emissions for other compounds is much lower (about a factor of 15-20) because they are mostly temperature dependent pool emissions from evergreen vegetation. For ISOP, the dominance of the emissions in the south over the emissions in the north is more pronounced in January than in June. This can be explained with the much steeper latitudinal gradient of PAR in winter. In June, the average PAR level in southern Sweden is around $610 \mu \mathrm{mol} \mathrm{m}^{-2} \mathrm{~s}^{-1}$ while 


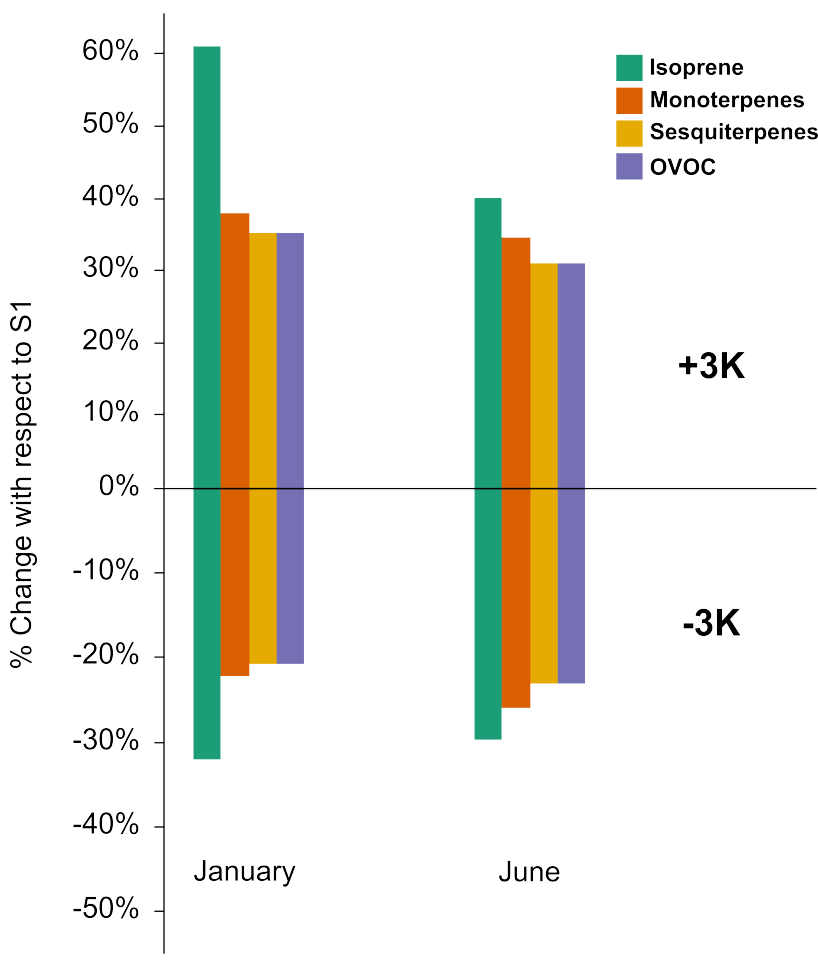

Fig. 8. Sensitivity of emissions to air temperature for S1 inventory in January and June 2006 (original countries). The sensitivities in $\mathrm{S} 2$ and $\mathrm{S} 3$ are very similar with differences in the $\pm 1 \%$ range.

in southern Spain it is about $720 \mu \mathrm{mol} \mathrm{m}^{-2} \mathrm{~s}^{-1}$ (factor of 1.18 higher). In January, average PAR levels are $50 \mu \mathrm{molm}^{-2} \mathrm{~s}^{-1}$ and $230 \mu \mathrm{molm}^{-2} \mathrm{~s}^{-1}$ for southern Sweden and southern Spain (factor of 4.6 higher), respectively.

For all compounds except ISOP, it is remarkable that Scotland as well as Northern Ireland are important emission regions in January in S1 and S2. We attribute this to the presence of the evergreen Picea sitchensis with its high basal emission rates. In S2, Austria is more pronounced as a MT emitting region in winter. For SQT, especially for S1 and S3, the dominance of the Northern countries is more pronounced in January than in June because in summer, the southern countries can compensate lower forest density with higher temperatures. The OVOC difference between summer and winter is dependent on the inventory. In S3, the distribution in summer and winter is similar. In S1, the Iberian Peninsula, Scotland, Southern and Eastern France as well as Western Germany are more important (in relative terms) in winter than in summer. In S2, a similar effect is observed.

In order to compare the diurnal cycle in the six climatic zones for June 2006, we again apply the concept of the "common countries" (which are represented in all three inventories) because otherwise, the scales might differ strongly due to missing data. First of all, the zonal diurnal cycles of temperature and PAR (Fig. Supp12) show that the temporal behaviour is dependent on the zone. The maxima of both tem- perature and PAR have the same order of magnitude for all zones, except that the zone "Polar" experiences higher levels of PAR than "Cold with cold summer" while for the temperatures the opposite is true. This can be explained with the elevated location of the "Polar" regions, which leads to cooler climate but is often located above the cloud cover. The peaks of radiation are sharper than for temperature because of the accumulation of heat during the day. This is also the reason for the fact that the time of the maximum is later in temperature than in PAR. The strongest diurnal amplitude of ISOP (Fig. Supp13) is observed for the "temperate dry summer" zone. The general shape of the diurnal cycle is similar in all zones for all inventories. In contrast to all other compounds, ISOP emissions are zero during night hours because of its strong dependence on PAR. If there is no light available, there can be no photosynthesis and hence no isoprene emission (Fig. 2). The same is the case for the synthesis fraction of the MT, but the pool emissions of MT persist in the dark. The time of the maximum of the ISOP emissions seems to be almost independent of the zone or the inventory and is reached at 12:00 UTC. For MT, the diurnal cycles are slightly broader than the cycles of ISOP (Fig. Supp14). This can be explained by the lower sensitivity of MT emissions to PAR and temperatures being high enough for significant emissions at dusk and dawn. Also, two distinct maxima are visible, the earlier one corresponding to the peak of PAR and the later corresponding to the peak of temperature. To some extent, this behaviour is also visible in the diurnal cycle of ISOP, but there, the temperature peak is less pronounced. In both S1 and S3, the "arid" and "temperate with dry summer" zones are clearly higher than the other zones, in S2, "temperate with dry summer" is the zone with highest emissions of MT. In the case of SQT (Fig. Supp15), both cold zones produce higher average emissions than the other zones for all inventories. This is mostly due to the fact that birches (Betula sp.), which are strong emitters of SQT are important trees in these climatic zones. Here, the peaks are even broader than for MT. Maximum emissions for all compounds in S2 are lower than in the other inventories, except for OVOC which looks similar in all three inventories (Fig. Supp16).

\subsection{Sensitivity of BVOC emissions to temperature and land-cover}

We tested the sensitivity of the emissions to temperature by running the model for January and June 2006 with air temperatures increased and decreased by $3 \mathrm{~K}$ (Fig. 8). The response was very similar for all inventories, therefore only the results for $\mathrm{S} 1$ are discussed here.

As expected, the increase of emissions when temperatures are higher is stronger than the decrease when temperature is lowered by the same amount for both January and June. ISOP shows the strongest difference of response to temperature increase between summer and winter: while in January, ISOP emissions increase $60 \%$, the increase is only $40 \%$ in June. 


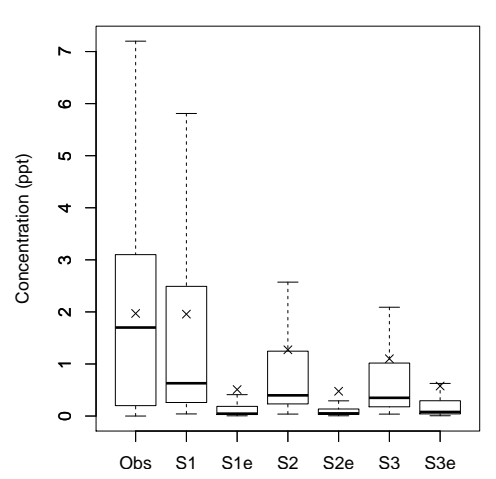

(a) Isoprene January 2006

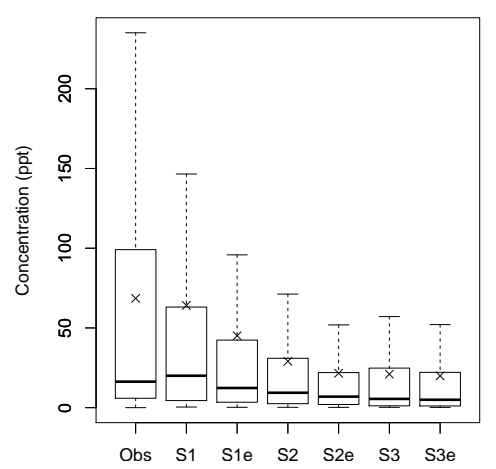

(c) Isoprene June 2006

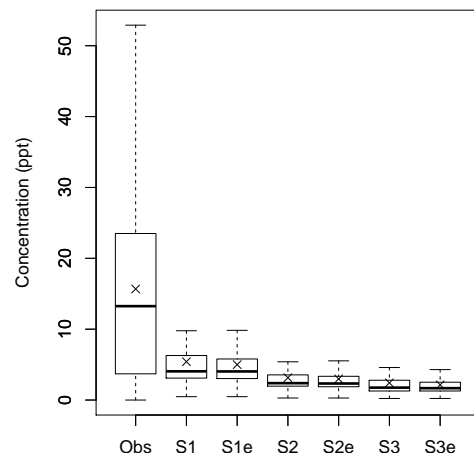

(b) Monoterpenes January 2006

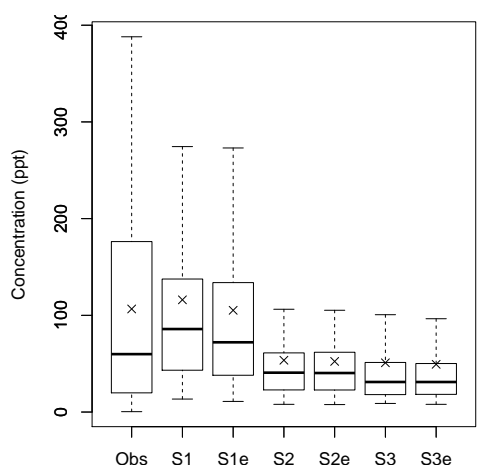

(d) Monoterpenes June 2006

Fig. 9. Observed (Obs) versus modelled concentrations at Hohenpeissenberg for S1-S3 and the corresponding scenarios with enzyme seasonality $\mathrm{S} 1 \mathrm{e}-\mathrm{S} 3 \mathrm{e}$. The boxes indicate the interquartile range, the median is the horizontal line in the box and the crosses indicate the averages. The whiskers extend to a value that is 1.5 times the interquartile range from the box.

This can be explained by the fact that higher temperatures in winter allow to compensate for less light, while in summer, the emissions saturate.

The differences between the species are considerable: ISOP shows the strongest response because the environmental correction function $\gamma_{\mathrm{S}}$ of the synthesis species is steeper at temperatures below $30^{\circ} \mathrm{C}$ (see Fig. 1) than for the other compounds. MT follow because of the synthesis part which are controlled by the same environmental correction function as ISOP. At the lower end of the scale are SQT and OVOC, which show the same factor because their environmental correction function $\gamma_{\mathrm{P}}$ is less steep in this temperature range.

The temperature sensitivity of BVOC emissions depends on the climatic zone, which is not the case for SQT and OVOC (Tab. Supp9). In January, the ISOP emissions in the zone "Cold except summer" are most sensitive to temperature $(-35 \% ;+64 \%)$ and the MT emission in zone "arid" react strongest $(-24 \% ;+41 \%)$. In June, the most sensitive zone is "polar" both for ISOP $(-32 \% ;+45 \%)$ as well as for MT $(-28 \% ;+39 \%)$.

There is some uncertainty in the derivation of tree-cover from the land-cover inventory because of the categorical nature of the land-cover data. Each pixel either represents a certain class or not. Typical categories include "Closed
( $>40 \%$ ) broadleaved deciduous forest $(>5 \mathrm{~m})$ ", which does not imply $100 \%$ coverage (a full list of forest categories is given in Tab. Supp5). We tested the influence of the landcover correction factors (see Eq. 7) and chose minimal (in the case above $40 \%$ broadleaved deciduous), average $(70 \%)$ and maximal values $(100 \%)$. The average values were used for the calculation of all emission data presented here, the other cases are just to determine the sensitivity to this factor in January and June 2006. For June 2006, total monthly BVOC emissions decreased up to $-27 \%$ with minimal and increased up to $+71 \%$ with maximal factors, while in January 2006, the changes in monthly BVOC emissions were $-54 \%$ and $+56 \%$ with minimal and maximal factors, respectively. The strongest decrease is in ISOP of S2 in June with $-60 \%$, the strongest increase is in SQT of S2 in June with $+96 \%$. Tab. Supp10 shows all the relative changes obtained.

We also tested the influence of the underlying land-cover inventory used when constructing S1 and S2. We applied the widely used USGS GLCC land-cover inventory (as delivered with WRF 3.2.1) as well as the GLC2000 data set (which was originally used to construct the (Skjøth et al., 2008a) data set). For both cases, the factors $f_{c}$ for $\mathrm{S} 1$ (Eq. 7) were simply set to 1.0 for pure conifer or broad-leaved forests and to 0.5 for mixed forests. For S2, $f_{c}$ was always 1.0. This choice of 
factors leads to an overestimation in the case of GLC2000, because grid cells which are partly covered by a certain vegetation type, appear as fully covered in the emission model.

For both vegetation inventories, we observed substantial differences when changing the land-cover inventory (see Figs. Supp17 and Supp18 for S1 and S2, respectively). In the case of $\mathrm{S} 1$, the annual emissions of all compounds are reduced when USGS GLCC is used instead of Globcover 2.2. The reduction of the annual emissions is strongest for ISOP $(-49 \%)$, followed by SQT $(-41 \%)$, MT $(-32 \%)$ and finally OVOC $(-12 \%)$. This is an indication that the total forest area is smaller in USGS GLCC, but also that the locations of the forests in the USGS GLCC data set is not in line with the regions defined by Skjøth et al. (2008a). USGS GLCC clearly contains less broad-leaved trees, which affects ISOP strongly. Fig. Supp19 shows the tree distribution of the USGS GLCC and GLC2000 land-cover inventories. If GLC2000 is used instead to construct S1, all compounds, except ISOP increase: OVOC $+13 \%$, MT $+6 \%$ and SQT $+3 \%$. ISOP, however is reduced by $40 \%$.

Inventory $\mathrm{S} 2$ is less prone to differences in forest position because the regions on which the vegetation types are defined are large. When using USGS GLCC instead of Globcover 2.2, the annual emissions of all compounds are also reduced: ISOP $-41 \%$, MT $-24 \%$, OVOC $-12 \%$ and SQT $-11 \%$. When using GLC2000 instead all but ISOP increase: $\mathrm{SQT}+41 \%$, OVOC $+29 \%$ and MT $+27 \%$. Annual ISOP is reduced as in the case of S1 but only by $-4 \%$.

This is an indication that the position of the forests does not agree among the three land-cover inventories USGS GLCC, GLC2000 and Globcover 2.2 and therefore that the choice of land-cover that is used will affect the modelling results.

\subsection{Comparison of measured and modelled BVOC concentrations}

In this study we compare our data with measurements at Hohenpeissenberg in Germany by DWD, which is part of the global atmosphere watch programme (GAW) (http://www. wmo.int/gaw/). This station is on a small hill (about $300 \mathrm{~m}$ above the surrounding countryside) at an elevation of about $980 \mathrm{~m}$ a.s.1.. This leads to a partial decoupling of the station with ground air, especially at night and in winter. Concentrations of BVOC were simulated using CAMx air quality model. For all three inventories both approaches to seasonality were considered (in S1-S3 only the biomass seasonality is included while S1e-S3e additionally includes enzyme seasonality). To perform the comparison, the lowest model layer (680 ma.s.1.) of the cell containing the station of Hohenpeissenberg was extracted. The area of this cell is about $260 \mathrm{~km}^{2}$. Even though the difference in altitude is small, Hohenpeissenberg is probably not representative for this large area - we expect the concentrations to be lower at Hohenpeissenberg, especially when the station is above an inversion layer unless there is an influence of transport from high areas with high emissions.

In an inter-comparison of VOC measurements of GAW (Rappenglück et al., 2006), the deviation of the ISOP measurements at Hohenpeissenberg from the reference value was found to be $1.4 \%$ and $-1.2 \%$ for two analytical instruments used. The accuracy of the measurement of MT was not investigated in that study, so we cannot assess the data quality for these compounds. There were two GC-MS/FID measurements per day (01:00 and 13:00 CET) with a sampling time of 20 min (Plass-Dülmer et al., 2002; Plass-Dülmer and Berresheim, 2006), resulting in 62 measurement points in January and 60 in June 2006. We use the measurements of ISOP and the sum of the measurements of $\alpha / \beta$-pinene, camphene, sabinene, myrcene, $\alpha$-phellandrene, carene and cymene (see Tab. Supp1 for structure and life-time information). In CAMx, the reaction rates of MT are the same as for $\alpha$-pinene, because this is thought to be the major MT emitted by plants (according to Steinbrecher et al. (2009), $\alpha$-pinene is the major MT emitted, however with an average fraction of only $29 \%$ ). $\alpha$-Pinene is one of the most long-lived MT considering $\mathrm{OH}$ reactivity only among the ones measured at Hohenpeissenberg (Tab. Supp1), but has a medium lifetime when reacting with $\mathrm{O}_{3}$ or the $\mathrm{NO}_{3}$ radical. Long-lived species such as cymene show almost constant concentrations both at day and at night at Hohenpeissenberg.

In general, the observed concentrations around noon are higher than the simulated ones (Fig. Supp21). The predicted peak concentrations occur around 07:00 p.m., which is due to the dynamics of the mixing layer height in the model, associated with a decline of $\mathrm{OH}$ and still low concentrations of $\mathrm{NO}_{3}$. From the available measurement data we cannot infer where the daily maximum is in reality. However, this type of diurnal cycle is consistent with literature data. For example, Handisides et al. (e.g. 2003) found the daily maximum of $\alpha$ - and $\beta$-pinene at 06:00 p.m. using measurement-intervals of two hours. Also consistent with this study is the fact that our daily maximum of ISOP occurs earlier, resulting from an earlier emission maximum of this compound as well as its higher reactivity compared to MT.

A comparison of the measured distribution with modelled data is shown in Fig. 9. The agreement of all inventories with measurements is better in June than in January. The average values of the observations are captured best by $\mathrm{S} 1$ for all cases except for MT in June where S1e predicts the average value better (Fig. 9). The agreement of S1 with the observed average is particularly good for ISOP in both seasons as well as for MT in summer. In winter, all scenarios clearly underestimate MT and ISOP, which is an indication that the seasonal correction might be too strong in winter. To assess the model performance, we use the root mean square error and its coefficient of variation and the correlation coefficient (refer to Sect. Supp2 of the Supplement for details). In summer, the coefficient of variation of the root-mean-square error CV(RSME) for ISOP is between 1.06 and 1.22 , for 
MT between 0.95 and 1.12. Model performance in terms of $\mathrm{CV}$ (RSME) in winter is worse than in summer, ranging between 1.76 and 1.95 for ISOP and between 1.16 and 1.25 for MT, which can partly be explained with increased anthropogenic influence on BVOC compounds in winter air. The full list of performance measures are given in Tab. Supp11. We compiled the model performance data graphically using Taylor diagrams (Taylor, 2001) (Fig. Supp22). When also enzyme seasonality is considered, model performance reacts heterogeneously. In general, the performance indicators do not change strongly, as can be seen in the Taylor diagrams (Fig. Supp22). However, with the exception of S1e for MT in June, the inclusion of the enzyme seasonality leads to a stronger underestimation of observed values, leading us to conclude that at least for Hohenpeissenberg and surroundings, the effect of the enzyme seasonality is either confounded with the biomass seasonality or otherwise overestimated. It is difficult to decide which vegetation inventory performs best. The Taylor diagrams show that the correlation coefficients of all models are similar for all cases but both the RMS difference between the modelled and observed values and the standard deviations vary between the models. In June, model performance is better for ISOP, while in January, it is better for MT. For ISOP in June, S2 seems to perform best, closely followed by S1 and S3. In January for both compounds the performance is not good, but the models are close to each other. For MT in June, S3 performs best, closely followed by S2. Also, the deviation between the model and the observations is not only due to tree inventories. An important source of uncertainty is the prediction of radiation by WRF and to a lesser extent the prediction of temperature. Also, model assumptions and oversimplification contribute to this difference. In particular for ISOP, anthropogenic sources contribute to atmospheric distributions which are not considered here (Reimann et al., 2000). In winter, ISOP measured at Hohenpeissenberg is strongly correlated to the anthropogenically emitted 1,3-butadiene or 1pentene (not shown). Especially in winter when lifetimes are longer, we expect regional traffic, residential wood burning and air mass transport from the city of Munich (the distance being about $55 \mathrm{~km}$ ) to influence Hohenpeissenberg air. There are considerable uncertainties in this comparison, which are however difficult to quantify. Contributing factors are uncertainties associated with the BVOC model (e.g. input data, emission factors/algorithms), uncertainties in the model of the gas phase chemistry (reaction rates, degradation pathways), uncertainties in the numerical weather prediction (temperature, radiation, mixing layer height and presence of inversion layers), measurement uncertainties and finally influences on the concentrations of target compounds that are not modelled here such as the anthropogenic contribution to BVOC compounds.

From this it is difficult to infer a ranking of the inventories. From a practical point of view it is desirable to use an inventory without gaps. For example Turkey and Ukraine con- tribute about $25 \%$ of all ISOP emission in S1, while these two countries have almost no emission in S2 and S3 due to limited data coverage. This makes $\mathrm{S} 1$ an attractive choice considering also its low values of the coefficient of variation of the root-mean-square error.

\section{Conclusions}

We developed a generalised model for estimating biogenic volatile organic compound emission which allows to compare different tree inventories, emission algorithms and light distribution schemes within the canopy. Using this model, we compared three different tree inventories for Europe and found that on continental scale, they produce similar monthly and hence annual totals for isoprene, monoterpenes, sesquiterpenes and oxygenated volatile organic compounds.

Even though the inventory with the highest thematic resolution (S3) features more than 110 vegetation types, all inventories agree that the diversity, viewed on a country-bycountry basis is not large. This is in line with the findings of the Ministerial Conference on the Protection of Forests in Europe, which suggest that most European forests consist only of two to three major species (Köhl and Rametsteiner, 2007). This could easily lead to the conclusion that a few tree species are enough to determine BVOC emissions in Europe. Our results however show that for the correct regional projection of BVOC emissions, a detailed speciation of the vegetation types is very important because the reference emission factors vary strongly between plants, even within the same genus.

The spatial distribution in the calculated BVOC emissions differs substantially. For some countries, such as Hungary or Finland the resulting differences in total BVOC emissions are factor of two between S1 and S3, although the total emissions over all countries represented in all three inventory types (common countries) are comparable. With the top ten plant types, we are able to explain $80 \%$ (OVOC) to $97 \%$ (ISOP) of the predicted biogenic VOC emissions. Some tree species, notably Eucalyptus sp. can make a significant contribution to BVOC levels even if their coverage seems insignificant. This suggests that including only the most common European tree species in BVOC modelling leads to a substantial bias in some areas. This also implies that forest inventories should not only be designed with an economic focus (wood productivity) but also contain information about species with high emission factors. We could show that the results are sensitive to the factors used to convert land-cover classes to tree types as well as to the landcover inventory used. This is a topic that needs to be addressed together with the remote sensing community. This problem is not only present for forest areas, but also in urban areas that can contain significant amount of woody vegetation (Konijnendijk et al., , 2005). Fast reacting BVOCs such as sesquiterpenes will affect aerosol formation mainly in the 
emission area. Here, Betula sp. is an exceptional species, because of 20 times higher reference emission factors of sequiterpenes compared to all other species included in our model.

To assess the impact of urban greening initiatives on air quality and ultimately human health, species with high emission factor require special attention. This topic was treated with respect to aeroallergens for the Copenhagen area (Skjøth et al., 2008b) and studied and discussed numerically for the West Midlands and Glasgow in the UK (McDonald et al., 2007). Overall these studies as well as our studies point towards the need for high resolution (both spatial as well as thematic) vegetation inventories.

Although it is not in the centre of this study, our assumptions lead to the conclusion that the vegetation type "agriculture" contributes significantly to BVOC emissions in Europe. This is in accordance with the study of Karl et al. (2009), where a more detailed inventory of agriculture was used. However, representing this land-cover class properly is difficult because changes in the cultivation patterns influence emission factors, foliar biomass as well as the vegetation density.

The importance of OVOC highlighted by our study may be a way to close the gap between observations and simulations of secondary organic aerosol. The OVOC species assumed here are merely a surrogate for hundreds of species actually found in biogenic emissions (Goldstein and Galbally, 2007), it is well possible that important precursors are yet to be identified. Our results suggests that OVOC is an important class of compounds to be investigated in Europe.

The inventory S1 based on Skjøth et al. (2008a) seems to be the best compromise between spatial and thematic resolution as well as completeness. However, our studies also points towards weaknesses in this inventory. One example is that some areas only have information on the genus level (e.g. Quercus sp.) while in other areas this information is available at the species level (e.g. Quercus ilex and Quercus rubra). The emission potential of isoprene between these oak species varies with a factor of about 300 . Tree inventories should therefore focus on delivering information on species level whenever possible.

The question whether enzymatic seasonality should be considered or not could not be answered conclusively. The fact, however, that isoprene emissions are suppressed almost completely up to including march leads us to conclude that these factors are not yet representative for all of Europe, especially in arid regions the early increase in greenness suggests the presence of isoprene emissions in March or even in February.

It is difficult to compare inventories that are not defined over the same countries, especially because regions with strong emissions such as Northwest Africa or Turkey are missing in some inventories. Additionally, there is a lack of long-term BVOC observations in Europe. It would be beneficial if at least isoprene would be measured at more sites than today in order to facilitate BVOC inventory development and validation of the models and their input data in relation to air quality issues.

\section{Supplementary material related to this article is available online at: http://www.atmos-chem-phys.net/13/ 1689/2013/acp-13-1689-2013-supplement.pdf.}

Acknowledgements. The comments of the two anonymous reviewers are very much appreciated and helped to improve this paper substantially. We are grateful to have received financial support by the Swiss Federal Office of the Environment (FOEN). Calculations of meteorological data where carried out using resources of the the Swiss National Supercomputing Centre (CSCS). We thank Renate Köble for providing access to the vegetation inventory S3. The authors thank ECMWF, MeteoSwiss, FUB, UBA, TNO, INFRAS, METEOTEST, ESA, NASA and USGS for providing various data. David Simpson provided a lot of helpful insights on BVOC. Martin Gysel provided his IGOR-Toolkit for the data analysis and supported this task. We thank Thomas Peter, Urs Baltensperger, Josef Dommen, Arnaud Praplan and Peter Barmet for their valuable input. Chris Emery, Greg Yarwood and Bonyoung Koo and all active members of the camxusers and the m3user mailing lists gave helpful advice concerning CAMx and visualisation. Some GIS data were taken from Natural Earth (http://www.naturalearthdata.com/). Colours are from Cynthia Brewer (http://www.ColorBrewer.org). We acknowledge the use of Excel2Latex by Kirill Müller, Andrew Hawryluk, and Joachim Marder which saved us a lot of time by accurately reproducing Excel tables with $\mathrm{LAT}_{\mathrm{E} X}$. Last but not least we would like to thank the team of Copernicus, especially Sarah Otto, Natascha Töpfer and Frauke Jurgeleit for the excellent support we received.

Edited by: A. Kiendler-Scharr

\section{References}

Aksoyoglu, S., Keller, J., Barmpadimos, I., Oderbolz, D., Lanz, V. A., Prévôt, A. S. H., and Baltensperger, U.: Aerosol modelling in Europe with a focus on Switzerland during summer and winter episodes, Atmos. Chem. Phys., 11, 7355-7373, doi:10.5194/acp11-7355-2011, 2011.

Andreani-Aksoyoglu, S. and Keller, J.: Estimates of monoterpene and isoprene emissions from the forests in Switzerland, J. Atmos. Chem., 20, 71-87, doi:10.1007/BF01099919, 1995.

Andreani-Aksoyoglu, S., Keller, J., Prévôt, A. S. H., Baltensperger, U., and Flemming, J.: Secondary aerosols in Switzerland and northern Italy: Modeling and sensitivity studies for summer 2003, J. Geophys. Res., 113, D06303, doi:10.1029/2007JD009053, 2008.

Arneth, A. and Niinemets, U.: Induced BVOCs: how to bug our models?, Trends Plant Sci., 15, 118-125, doi:10.1016/j.tplants.2009.12.004, 2010.

Arneth, A., Schurgers, G., Lathiere, J., Duhl, T., Beerling, D. J., Hewitt, C. N., Martin, M., and Guenther, A.: Global terrestrial isoprene emission models: sensitivity to variability in 
climate and vegetation, Atmos. Chem. Phys., 11, 8037-8052, doi:10.5194/acp-11-8037-2011, 2011.

Atkinson, R. and Arey, J.: Gas-phase tropospheric chemistry of biogenic volatile organic compounds: a review, Atmos. Environ., 37, 197-219, doi:10.1016/S1352-2310(03)00391-1, 2003.

Bäck, J., Aalto, J., Henriksson, M., Hakola, H., He, Q., and Boy, M.: Chemodiversity of a Scots pine stand and implications for terpene air concentrations, Biogeosciences, 9, 689-702, doi:10.5194/bg-9-689-2012, 2012.

Baghi, R., Helmig, D., Guenther, A., Duhl, T., and Daly, R.: Contribution of flowering trees to urban atmospheric biogenic volatile organic compound emissions, Biogeosciences, 9, 3777-3785, doi:10.5194/bg-9-3777-2012, 2012.

Baldocchi, D. D., Hutchison, B. A., Matt, D. R., and McMillen, R. T.: Canopy Radiative Transfer Models for Spherical and Known Leaf Inclination Angle Distributions: A Test in an OakHickory Forest, J. Appl. Ecol., 22, 539-555, 1985.

Battey, N. H.: Aspects of seasonality, J. Exp. Bot., 51, 1769, doi:10.1093/jexbot/51.352.1769, 2000

Berg, A. R., Heald, C. L., Hartz, K. E. H., Hallar, A. G., Meddens, A. J. H., Hicke, J. A., Lamarque, J. F., Tilmes, S.:The impact of bark beetle infestation on monoterpene emissions and secondary organic aerosol formation in Western North America, Atmos. Chem. Phys. Discuss.,12, 29763-29800, doi:10.5194/acpd12-29763-2012, 2012.

Boelman, N. T., Stieglitz, M., Rueth, H. M., Sommerkorn, M., Griffin, K. L., Shaver, G. R., and Gamon, J. A.: Response of NDVI, biomass, and ecosystem gas exchange to long-term warming and fertilization in wet sedge tundra, Oecologia, 135, 414-421, 2003.

Bontemps, S., Defourny, P., Bogaert, E. V., Arino, O., Kalogirou, V., and Perez, J. R.: Globcover Products Description and Validation Report, Tech. rep., ESA, 2011.

Bracho-Nunez, A., Welter, S., Staudt, M., Kesselmeier, J.:Plantspecific volatile organic compound emission rates from young and mature leaves of Mediterranean vegetation, J. Geophys. Res., 116, D16304, doi:10.1029/2010JD015521, 2011.

Brewer, C. A.: Color Brewer, http://www.ColorBrewer.org, last access: 24 November 2011.

Carlton, A. G., Wiedinmyer, C., and Kroll, J. H.: A review of Secondary Organic Aerosol (SOA) formation from isoprene, Atmos. Chem. Phys., 9, 4987-5005, doi:10.5194/acp-9-4987-2009, 2009

Carlton, A. G., Pinder, R. W., Bhave, P. V., and Pouliot, G. A.: To What Extent Can Biogenic SOA be Controlled?, Environ. Sci. Technol., 44, 3376-3380, doi:10.1021/es903506b, 2010.

Chameides, W. L., Lindsay, R. W., Richardson, J., and Kiang, C. S.: The role of biogenic hydrocarbons in urban photochemical smog: Atlanta as a case study, Science, 241, 1473, doi:10.1126/science.3420404, 1988.

Ciccioli, P., Brancaleoni, E., Frattoni, M., Cecinato, A., and Pinciarelli, L.: Determination of volatile organic compounds (VOC) emitted from biomass burning of mediterranean vegetation species by GC-MS, Anal. Lett., 34, 937-955, doi:10.1081/AL100103604, 2001.

Ciccioli, P., Brancaleoni, E., Frattoni, M., Marta, S., Brachetti, A., Vitullo, M., Tirone, G., and Valentini, R.: Relaxed eddy accumulation, a new technique for measuring emission and deposition fluxes of volatile organic compounds by capillary gas chromatography and mass spectrometry, J. Chromatogr. A, 985, 283-296, doi:10.1016/S0021-9673(02)01731-4, 2003.
Claeys, M., Graham, B., Vas, G., Wang, W., Vermeylen, R., Pashynska, V., Cafmeyer, J., Guyon, P., Andreae, M. O., Artaxo, P., and Maenhaut, W.: Formation of Secondary Organic Aerosols Through Photooxidation of Isoprene, Science, 303, 1173-1176, 2004.

Curci, G., Beekmann, M., Vautard, R., Smiatek, G., Steinbrecher, R., Theloke, J., and Friedrich, R.: Modelling study of the impact of isoprene and terpene biogenic emissions on European ozone levels, Atmos. Environ., 43, 1444-1455, doi:10.1016/j.atmosenv.2008.02.070, 2009.

Duhl, T. R., Helmig, D., and Guenther, A.: Sesquiterpene emissions from vegetation: a review, Biogeosciences, 5, 761-777, doi:10.5194/bg-5-761-2008, 2008.

ENVIRON: User's Guide, Comprehensive Air Quality Model with Extensions (CAMx). Version 5.30, Tech. rep., ENVIRON International Corporation, Novato, 2010.

Evrendilek, F. and Gulbeyaz, O.: Deriving vegetation dynamics of natural terrestrial ecosystems from MODIS NDVI/EVI data over Turkey, Sensors, 8, 5270-5302, doi:10.3390/s8095270, 2008.

Fares, S., Gentner D.R, Park J.-H., Ormeno, E., Karlik,J., Goldstein, A.H.: Biogenic emissions from Citrus species in California, Atmos. Environ., 45, 4557-4568 doi:10.1016/j.atmosenv.2011.05.066, 2011.

Goldstein, A. H. and Galbally, I. E.: Known and Unexplored Organic Constituents in the Earth's Atmosphere, Environ. Sci. Technol., 41, 1514-1521, doi:10.1021/es072476p, 2007.

Guenther, A.: Seasonal and spatial variations in natural volatile organic compound emissions, Ecol. Appl., 7, 34-45, 1997.

Guenther, A., Zimmerman, P. R., Harley, P. C., Monson, R. K., and Fall, R.: Isoprene and Monoterpene Emission Rate Variability: Model Evaluations and Sensitivity Analyses, J. Geophys. Res., 98, 12609-12617, doi:10.1029/93JD00527, 1993.

Guenther, A., Hewitt, C. N., Erickson, D., Fall, R., Geron, C., Graedel, T., Harley, P., Klinger, L., and Lerdau, M.: A global model of natural volatile organic compound emissions, J. Geophys. Res.-Atmos., 100, 8873-8892, 1995.

Guenther, A., Karl, T., Harley, P., Wiedinmyer, C., Palmer, P. I., and Geron, C.: Estimates of global terrestrial isoprene emissions using MEGAN (Model of Emissions of Gases and Aerosols from Nature), Atmos. Chem. Phys., 6, 3181-3210, doi:10.5194/acp-63181-2006, 2006.

Guenther, A., Jiang, X., Heald, C. L., Sakulyanontvittaya, T., Duhl, T., Emmons, L. K., Wang, X.: The Model of Emissions of Gases and Aerosols from Nature version 2.1 (MEGAN2.1): an extended and updated framework for modeling biogenic emissions, Geosci. Model. Dev., 5, 1471-1492, doi:10.5194/gmd-5-14712012, 2012.

Hakola, H., Laurila, T., Lindfors, V., Hellén, H., Gaman, A., and Rinne, J.: Variation of the VOC emission rates of birch species during the growing season, Boreal Environ. Res., 6, 237-249, 2001.

Hakola, H., Tarvainen, V., Bäck, J., Ranta, H., Bonn, B., Rinne, J., and Kulmala, M.: Seasonal variation of mono- and sesquiterpene emission rates of Scots pine, Biogeosciences, 3, 93-101, doi:10.5194/bg-3-93-2006, 2006.

Hallquist, M., Wenger, J. C., Baltensperger, U., Rudich, Y., Simpson, D., Claeys, M., Dommen, J., Donahue, N. M., George, C., Goldstein, A. H., Hamilton, J. F., Herrmann, H., Hoffmann, T., Iinuma, Y., Jang, M., Jenkin, M. E., Jimenez, J. L., 
Kiendler-Scharr, A., Maenhaut, W., McFiggans, G., Mentel, Th. F., Monod, A., Prévôt, A. S. H., Seinfeld, J. H., Surratt, J. D., Szmigielski, R., and Wildt, J.: The formation, properties and impact of secondary organic aerosol: current and emerging issues, Atmos. Chem. Phys., 9, 5155-5236, doi:10.5194/acp-9-51552009, 2009.

Handisides, G. M., Plass-Dülmer, C., Gilge, S., Bingemer, H., and Berresheim, H.: Hohenpeissenberg Photochemical Experiment (HOPE 2000): Measurements and photostationary state calculations of $\mathrm{OH}$ and peroxy radicals, Atmos. Chem. Phys., 3, 15651588, doi:10.5194/acp-3-1565-2003, 2003.

Hansen, U., Seufert, G.:Temperature and light dependence of $\beta$ caryophyllene emission rates, J. Geophys. Res., 108, 4801, doi:10.1029/2003JD003853, 2003.

Hartley, A., Pekel, J.-F., Ledwith, M., Champeaux, J.-L., Badts, E. D., and Bartalev, S. A.: The Land Cover Map for Europe in the Year 2000, http://bioval.jrc.ec.europa.eu/products/glc2000/ glc2000.php, 2006.

Hickler, T., Vohland, K., Feehan, J., Miller, P. A., Smith, B., Costa, L., Giesecke, T., Fronzek, S., Carter, T. R., and Cramer, W.: Projecting the future distribution of European potential natural vegetation zones with a generalized, tree species-based dynamic vegetation model, Global Ecol. Biogeogr., 21, 50-63, doi:10.1111/j.1466-8238.2010.00613.x, 2012.

Hodzic, A., Jimenez, J. L., Madronich, S., Aiken, A. C., Bessagnet, B., Curci, G., Fast, J., Lamarque, J.-F., Onasch, T. B., Roux, G., Schauer, J. J., Stone, E. A., and Ulbrich, I. M.: Modeling organic aerosols during MILAGRO: importance of biogenic secondary organic aerosols, Atmos. Chem. Phys., 9, 6949-6981, doi:10.5194/acp-9-6949-2009, 2009.

Huete, A., Justice, C., and van Leeuwen, W.: MODIS vegetation index (MOD13) algorithm theoretical basis document, Tech. rep., NASA, 1999.

Ingemarsson, R., Nilsson, U., Nilsson, M., Pedersen, J. R., and Olsson, J. O.: Slow pyrolysis of spruce and pine samples studied with GC/MS and GC/FTIR/FID, The Chemosphere, 36, 28792889, doi:10.1016/S0045-6535(97)10245-4, 1998.

Janjic, Z. I.: The step-mountain eta coordinate model: Further developments of the convection, viscous sublayer, and turbulence closure schemes, Mon. Weather Rev., 122, 927-945, 1994.

Jimenez, J. L., Canagaratna, M. R., Donahue, N. M., Prevot, A. S. H., Zhang, Q., Kroll, J. H., DeCarlo, P. F., Allan, J. D., Coe, H., Ng, N. L., Aiken, A. C., Docherty, K. S., Ulbrich, I. M., Grieshop, A. P., Robinson, A. L., Duplissy, J., Smith, J. D., Wilson, K. R., Lanz, V. A., Hueglin, C., Sun, Y. L., Tian, J., Laaksonen, A., Raatikainen, T., Rautiainen, J., Vaattovaara, P., Ehn, M., Kulmala, M., Tomlinson, J. M., Collins, D. R., Cubison, M. J., E, Dunlea, J., Huffman, J. A., Onasch, T. B., Alfarra, M. R., Williams, P. I., Bower, K., Kondo, Y., Schneider, J., Drewnick, F., Borrmann, S., Weimer, S., Demerjian, K., Salcedo, D., Cottrell, L., Griffin, R., Takami, A., Miyoshi, T., Hatakeyama, S., Shimono, A., Sun, J. Y., Zhang, Y. M., Dzepina, K., Kimmel, J. R., Sueper, D., Jayne, J. T., Herndon, S. C., Trimborn, A. M., Williams, L. R., Wood, E. C., Middlebrook, A. M., Kolb, C. E., Baltensperger, U., and Worsnop, D. R.: Evolution of Organic Aerosols in the Atmosphere, Science, 326, 1525-1529, doi:10.1126/science.1092805, 2009.

Kanakidou, M., Tsigaridis, K., Dentener, F. J., and Crutzen, P. J.: Human-activity-enhanced formation of organic aerosols by bio- genic hydrocarbon oxidation, J. Geophys. Res., 105, 9243-9354, doi:10.1029/1999JD901148, 2000.

Karl, M., Guenther, A., Köble, R., Leip, A., and Seufert, G.: A new European plant-specific emission inventory of biogenic volatile organic compounds for use in atmospheric transport models, Biogeosciences, 6, 1059-1087, doi:10.5194/bg-6-1059-2009, 2009

Karlsen, S. R., Ramfjord, H., Høgda, K. A., Johansen, B., Danks, F. S., and Brobakk, T. E.: A satellite-based map of onset of birch (Betula) flowering in Norway, Aerobiologia, 25, 15-25, doi:10.1007/s10453-008-9105-3, 2009.

Keenan, T., Niinemets, Ü., Sabate, S., Gracia, C., and Peñuelas, J.: Process based inventory of isoprenoid emissions from European forests: model comparisons, current knowledge and uncertainties, Atmos. Chem. Phys., 9, 4053-4076, doi:10.5194/acp-94053-2009, 2009.

Keller, J., Andreani-Aksoyoglu, S., and Joss, U.: Inventory of natural emissions in Switzerland, Air Pollution III, 2, 339-346, 1995.

Kniezys, F. X., Shettle, E. P., Abreu, L. W., Chetwynd, J. H., Anderson, G. P., Gallery, W. O., Selby, J. E. A., and Clough, S. A.: User guide to LOWTRAN 7, Tech. rep., Air Force Geophysics Laboratory, Hanscom AFB, MA, 1988.

Köble, R. and Seufert, G.: Novel maps for forest tree species in Europe, in: Proceedings of the 8th European symposium on the physico-chemical behaviour of air pollutants: A changing atmosphere, 17-20, 2001.

Köhl, M. and Rametsteiner, E.: State of Europe's Forests 2007. The MCPFE report on sustainable forest management in Europe, Tech. Rep. 83-922396-8-7, United Nations Economic Commission for Europe and Food and Agriculture Organization of the United Nations, 2007.

Konijnendijk, C. C.: Urban forests and trees: a reference book, Springer Verlag, Heidelberg, Germany, 520 pp., 2005.

Koppmann, R.: Volatile organic compounds in the atmosphere, Wiley-Blackwell, Oxford, UK, 518 pp., 2007.

Kuenen, J., Van der Gon, H. D., Visschedijk, A., Van der Brugh, H., and Van Gijlswijk, R.: MACC European emission inventory for the years 2003-2007, Tech. rep., TNO, 2011.

Lanz, V. A., Alfarra, M. R., Baltensperger, U., Buchmann, B., Hueglin, C., Szidat, S., Wehrli, M. N., Wacker, L., Weimer, S., Caseiro, A., Puxbaum, H., and Prevot, A. S. H.: Source Attribution of Submicron Organic Aerosols during Wintertime Inversions by Advanced Factor Analysis of Aerosol Mass Spectra, Environ. Sci. Technol., 42, 214-220, doi:10.1021/es0707207, 2008.

Lanz, V. A., Prévôt, A. S. H., Alfarra, M. R., Weimer, S., Mohr, C., DeCarlo, P. F., Gianini, M. F. D., Hueglin, C., Schneider, J., Favez, O., D'Anna, B., George, C., and Baltensperger, U.: Characterization of aerosol chemical composition with aerosol mass spectrometry in Central Europe: an overview, Atmos. Chem. Phys., 10, 10453-10471, doi:10.5194/acp-10-10453-2010, 2010.

Lehning, A., Zimmer, W., Zimmer, I., and Schnitzler, J. P.: Modeling of annual variations of oak (Quercus robur L.) isoprene synthase activity to predict isoprene emission rates, J. Geophys. Res., 106, 3157-3166, 2001.

Leuzinger, S. and Körner, C.: Tree species diversity affects canopy leaf temperatures in a mature temperate forest, Agr. Forest Meteorol., 146, 29-37, doi:10.1016/j.agrformet.2007.05.007, 2007.

Llusià, J., Peñuelas, J., and Gimeno, B. S.: Seasonal and speciesspecific response of VOC emissions by Mediterranean woody plant to elevated ozone concentrations, Atmos. Environ., 36, 
3931-3938, doi:10.1016/S1352-2310(02)00321-7, 2002.

Lucas-Barbosa, D., van Loon, J. J. A., and Dicke, M.: The effects of herbivore-induced plant volatiles on interactions between plants and flower-visiting insects, Phytochemistry Plant-Insect Interactions, 72, 1647-1654, doi:10.1016/j.phytochem.2011.03.013, 2011.

McDonald, A. G., Bealey, W. J., Fowler, D., Dragosits, U., Skiba, U., Smith, R. I., Donovan, R. G., Brett, H. E., Hewitt, C. N., and Nemitz, E.: Quantifying the effect of urban tree planting on concentrations and depositions of $\mathrm{PM}_{10}$ in two UK conurbations, Atmos. Environ., 41, 8455-8467, doi:10.1016/j.atmosenv.2007.07.025, 2007.

Merlo, M. and Croitoru, L.: Valuing Mediterranean forests: towards total economic value, CABI Publishing Series, CABI, Wallingford, UK, 416 pp., 2005.

Michalakes, J., Dudhia, J., Gill, D., Henderson, T., Klemp, J., Skamarock, W., and Wang, W.: The weather research and forecast model: Software architecture and performance, in: 11th ECMWF Workshop on the Use of High Performance Computing In Meteorology, 156-168, 2004.

Mohr, C., DeCarlo, P. F., Heringa, M. F., Chirico, R., Slowik, J. G., Richter, R., Reche, C., Alastuey, A., Querol, X., Seco, R., Peñuelas, J., Jiménez, J. L., Crippa, M., Zimmermann, R., Baltensperger, U., and Prévôt, A. S. H.: Identification and quantification of organic aerosol from cooking and other sources in Barcelona using aerosol mass spectrometer data, Atmos. Chem. Phys., 12, 1649-1665, doi:10.5194/acp-12-1649-2012, 2012.

Nakaji, T., Ide, R., Oguma, H., Saigusa, N., and Fujinuma, Y.: Utility of spectral vegetation index for estimation of gross $\mathrm{CO}_{2}$ flux under varied sky conditions, Remote Sens. Environ., 109, 274284, doi:10.1016/j.rse.2007.01.006, 2007.

Niinemets, U.: Stomatal conductance alone does not explain the decline in foliar photosynthetic rates with increasing tree age and size in Picea abies and Pinus sylvestris, Tree Physiol., 22, 515535, 2002.

Niinemets, U.: A review of light interception in plant stands from leaf to canopy in different plant functional types and in species with varying shade tolerance, Ecol. Res., 25, 693-714, doi:10.1007/s11284-010-0712-4, 2010a.

Niinemets, U.: Mild versus severe stress and BVOCs: thresholds, priming and consequences, Trends Plant Sci., 15, 145-153, doi:10.1016/j.tplants.2009.11.008, 2010b.

Niinemets, U., Monson, R. K., Arneth, A., Ciccioli, P., Kesselmeier, J., Kuhn, U., Noe, S. M., Penuelas, J., Staudt, M.:The emission factor of volatile isoprenoids: caveats, model algorithms, response shapes and scaling, Biogeosciences, 7, 1809-1832, doi:10.5194/bg-7-1809-2010, 2010.

Niinemets, U., Kuhn, U., Harley, P. C., Staudt, M., Arneth, A., Cescatti, A., Ciccioli, P., Copolovici, L., Geron, C., Guenther, A.:Estimations of isoprenoid emission capacity from enclosure studies: measurements, data processing, quality and standardized measurement protocols, Biogeosciences, 8, 2209-2246, doi:10.5194/bg-8-2209-2011, 2011.

Oderbolz, D. C., Barmpadimos, I., and Aksoyoglu, S.: CAMxRunner - a modular framework for efficient chemical transport modelling, Int. J. Environ. Pollut., 1/2/3/4, 117-125, doi:10.1504/IJEP.2012.049658, 2012.

Ormeño, E., Mévy, J. P., Vila, B., Bousquet-Mélou, A., Greff, S., Bonin, G., and Fernandez, C.: Water deficit stress induces different monoterpene and sesquiterpene emission changes in Mediterranean species. Relationship between terpene emissions and plant water potential, The Chemosphere, 67, 276-284, doi:10.1016/j.chemosphere.2006.10.029, 2007.

Peñuelas, J. and Llusià, J.: The Complexity of Factors Driving Volatile Organic Compound Emissions by Plants, Biol. Plantarum, 44, 481-487, doi:10.1023/A:1013797129428, 2001.

Peel, M. C., Finlayson, B. L., and McMahon, T. A.: Updated world map of the Köppen-Geiger climate classification, Hydrol. Earth Syst. Sci., 11, 1633-1644, doi:10.5194/hess-11-16332007, 2007.

Plass-Dülmer, C. and Berresheim, H.: Volatile organic compound measurements at Hohenpeissenberg as part of GAW, in: The German contribution to the WMO GAW programme: upon the 225th anniversary of GAW Hohenpeissenberg observatory, edited by: Fricke, W., Barrie, L. A., and Schleyer, R., 167, 59-63, 2006.

Plass-Dülmer, C., Michl, K., Ruf, R., and Berresheim, H.: C2C8 Hydrocarbon measurement and quality control procedures at the Global Atmosphere Watch Observatory Hohenpeissenberg, J. Chromatogr. A, 953, 175-197, doi:10.1016/S00219673(02)00128-0, 2002.

Rappenglück, B., Apel, E., Bauerfeind, M., Bottenheim, J., Brickell, P., Cavolka, P., Cech, J., Gatti, L., Hakola, H., Honzak, J., Junek, R., Martin, D., Noone, C., Plass-Dülmer, C., Travers, D., and Wang, D.: The first VOC intercomparison exercise within the Global Atmosphere Watch (GAW), Atmos. Environ., 40, 75087527, doi:10.1016/j.atmosenv.2006.07.016, 2006.

Rasmussen, L. E. L. and Perrin, T. E.: Physiological Correlates of Musth: Lipid Metabolites and Chemical Composition of Exudates, Physiol. Behav., 67, 539-549, doi:10.1016/S00319384(99)00114-6, 1999.

Reimann, S., Calanca, P., and Hofer, P.: The anthropogenic contribution to isoprene concentrations in a rural atmosphere, Atmos. Environ., 34, 109-115, doi:10.1016/S1352-2310(99)00285-X, 2000.

Ross, I. U.: The radiation regime and architecture of plant stands, Vol. 3, Dr. W. Junk Publishers, The Hague, NL, 393 pp., 1981.

Rouvière, A., Brulfert, G., Baussand, P., and Chollet, J.P.: Monoterpene source emissions from Chamonix in the Alpine Valleys, Atmos. Environ., 40, 3613-3620, doi:10.1016/j.atmosenv.2005.09.058, 2006.

Salerno-Kennedy, R. and Cashman, K. D.: Potential applications of breath isoprene as a biomarker in modern medicine: a concise overview, Wiener Klin. Wochenschr., 117, 180-186, doi:10.1007/s00508-005-0336-9, 2005.

Schmidt, H.: Kronen- und Zuwachsuntersuchungen an Fichten des bayerischen Alpenvorlandes, Forstwiss. Centralbl., 72, 276-286, doi:10.1007/BF01819340, 1953.

Schnitzler, J. P., Lehning, A., and Steinbrecher, R.: Seasonal pattern of isoprene synthase activity in Quercus robur leaves and its significance for modeling isoprene emission rates, Bot. Acta, 110, 240-243, 1997.

Schönwitz, R., Merk, L., and Ziegler, H.: Naturally occurring monoterpenoids in needles of Picea abies (L.) Karst, TreesStruct. Funct., 1, 88-93, doi:10.1007/BF00203576, 1987.

Simpson, D., Winiwarter, W., Börjesson, G., Cinderby, S., Ferreiro, A., Guenther, A., Hewitt, C. N., Janson, R., Khalil, M. A. K., and Owen, S.: Inventorying emissions from nature in Europe, J. Geophys. Res., 104, 8113-8152, doi:10.1029/98JD02747, 1999. 
Simpson, D., Benedictow, A., Berge, H., Bergström, R., Emberson, L. D., Fagerli, H., Hayman, G. D., Gauss, M., Jonson, J. E., Jenkin, M. E., Nyíri, A., Richter, C., Semeena, V. S., Tsyro, S., Tuovinen, J.-P., Valdebenito, Á., and Wind, P.: The EMEP MSCW chemical transport model - Part 1: Model description, Atmos. Chem. Phys. Discuss., 12, 3781-3874, doi:10.5194/acpd12-3781-2012, 2012.

Skjøth, C. A., Geels, C., Hvidberg, M., Hertel, O., Brandt, J., Frohn, L. M., Hansen, K. M., Hedegaard, G. B., Christensen, J. H., and Moseholm, L.: An inventory of tree species in Europe - An essential data input for air pollution modelling, Ecol. Modell., 217, 292-304, doi:10.1016/j.ecolmodel.2008.06.023, 2008a.

Skjøth, C. A., Sommer, J., Brandt, J., Hvidberg, M., Geels, C., Hansen, K. M., Hertel, O., Frohn, L. M., and Christensen, J. H.: Copenhagen - a significant source of birch (Betula) pollen?, I. J. Biometeorol., 52, 453-462, doi:10.1007/s00484-007-0139-y, 2008 b.

Smiatek, G. and Steinbrecher, R.: Temporal and spatial variation of forest VOC emissions in Germany in the decade 1994-2003, Regional biogenic emissions of reactive volatile organic compounds (BVOC) from forests: Process studies, modelling and validation experiments (BEWA2000), 40, 166-177, doi:10.1016/j.atmosenv.2005.11.071, 2006.

Staudt, M., Bertin, N., Frenzel, B., and Seufert, G.: Seasonal Variation in Amount and Composition of Monoterpenes Emitted by Young Pinus pinea Trees - Implications for Emission Modeling, J. Atmos. Chem., 35, 77-99, doi:10.1023/A:1006233010748, 2000 .

Steinbrecher, R., Smiatek, G., Köble, R., Seufert, G., Theloke, J., Hauff, K., Ciccioli, P., Vautard, R., and Curci, G.: Intra- and inter-annual variability of VOC emissions from natural and seminatural vegetation in Europe and neighbouring countries, Atmos. Environ., 43, 1380-1391, doi:10.1016/j.atmosenv.2008.09.072, 2009.

Stewart, H., Hewitt, C. N., and Bunce, R. G. H.: Assessing, mapping and quantifying the distribution of foliar biomass in Great Britain, Biomass Bioenerg., 32, 838-856, doi:10.1016/j.biombioe.2007.12.015, 2008.

Stewart, H. E., Hewitt, C. N., Bunce, R. G. H., Steinbrecher, R., Smiatek, G., and Schoenemeyer, T.: A highly spatially and temporally resolved inventory for biogenic isoprene and monoterpene emissions: Model description and application to Great Britain, J. Geophys. Res., 108, 4644, doi:10.1029/2002JD002694, 2003.
Street, R. A., Hewitt, C. N., and Mennicken, S.: Isoprene and monoterpene emissions from a Eucalyptus plantation in Portugal, J. Geophys. Res., 102, 15875-15887, doi:10.1029/97JD00010, 1997.

Strömvall, A.-M. and Petersson, G.: Conifer monoterpenes emitted to air by logging operations, Scand. J. Forest Res., 6, 253-258, doi:10.1080/02827589109382666, 1991.

Swanson, A. L., Lefer, B. L., Stroud, V., and Atlas, E.: Trace gas emissions through a winter snowpack in the subalpine ecosystem at Niwot Ridge, Colorado, Geophys. Res. Lett., 32, L03805, doi:10.1029/2004GL021809, 2005.

Szidat, S., Jenk, T. M., Synal, H.-A., Kalberer, M., Wacker, L., Hajdas, I., Kasper-Giebl, A., and Baltensperger, U.: Contributions of fossil fuel, biomass-burning, and biogenic emissions to carbonaceous aerosols in Zurich as traced by ${ }^{14} \mathrm{C}$, J. Geophys. Res., 111, D07206, doi:10.1029/2005JD006590, 2006.

Taylor, K. E.: Summarizing multiple aspects of model performance in a single diagram, J. Geophys. Res., 106, 7183-7192, 2001.

Tucker, C. J.: Red and photographic infrared linear combinations for monitoring vegetation, Remote Sens. Environ., 8, 127-150, doi:10.1016/0034-4257(79)90013-0, 1979.

UN-ECE: International Co-operative Programme on Assessment and Monitoring of Air Pollution Effects on Forests. Manual on methods and criteria for harmonized sampling, assessment, monitoring and analysis of the effects of air pollution on forests, http://icp-forests.net, 1998.

Uppala, S. M., Killberg, P. W., Simmons, A. J., Andrae, U., Bechtold, V. D. C., Fiorino, M., Gibson, J. K., Haseler, J., Hernandez, A., and Kelly, G. A.: The ERA-40 re-analysis, Q. J. Roy. Meteorol. Soc., 131, 2961-3012, doi:10.1256/qj.04.176, 2005.

Zimmer, W., Steinbrecher, R., Körner, C., and Schnitzler, J. P.: The process-based SIM-BIM model: towards more realistic prediction of isoprene emissions from adult Quercus petraea forest trees, Atmos. Environ., 37, 1665-1671, doi:10.1016/S13522310(03)00013-X, 2003. 